Fish and Fisheries

January 2017, Volume 18, Issue 1, Pages 1-21

http://dx.doi.org/10.1111/faf.12163

Achimer

http://archimer.ifremer.fr/doc/00333/44383/

(c) 2016 John Wiley \& Sons Ltd

\title{
Effects of biological, economic and management factors on tuna and billfish stock status
}

\author{
Pons Maite ${ }^{1,{ }^{*}}$, Branch Trevor A ${ }^{1}$, Melnychuk Michael $\mathrm{C}^{1}$, Jensen Olaf $\mathrm{P}^{2}$, Brodziak Jon ${ }^{3}$, \\ Fromentin Jean-Marc ${ }^{4}$, Harley Shelton $\mathrm{J}^{5}$, Haynie Alan $\mathrm{C}^{6}$, Kell Laurie $\mathrm{T}^{7}$, Maunder Mark $\mathrm{N}^{8}$, \\ Parma Ana $\mathrm{M}^{9}$, Restrepo Victor $\mathrm{R}^{10}$, Sharma Rishi ${ }^{11}$, Ahrens Robert ${ }^{12}$, Hilborn Ray ${ }^{1}$
}

${ }^{1}$ School of Aquatic and Fishery Sciences; University of Washington; Box 355020 Seattle WA 98195, USA

2 Department of Marine \& Coastal Science; Rutgers University; 71 Dudley Rd. New Brunswick NJ 08901 ,USA

${ }^{3}$ NOAA Fisheries; National Marine Fisheries Service; Pacific Islands Fisheries Science Center; 1845

Wasp Blvd. Honolulu HI 96818-5007, USA

${ }^{4}$ Ifremer; UMR MARBEC (Marine Biodiversity, exploitation and conservation), boulevard Jean Monnet; CS 3017134203 Sète Cedex, France

${ }^{5}$ Fisheries, Aquaculture and Marine Ecosystems Division; Secretariat of the Pacific Community; B.P. D5 98848 Noumea ,New Caledonia

${ }^{6}$ NOAA Fisheries; Alaska Fisheries Science Center; Bldg 47600 Sand Point Way NE Seattle WA 98115, USA

${ }^{7}$ ICCAT (International Commission for the Conservation of Atlantic Tunas) Secretariat; Corazón de María 828002 Madrid ,Spain

${ }^{8}$ IATTC (Inter-American Tropical Tuna Commission); 8901 La Jolla Shores Drive San Diego CA 920371508, USA

${ }^{9}$ Centro Nacional Patagónico - CONICET; Boulevard Brown 2915 (U9120ACD) Puerto Madryn

Chubut ,Argentina

${ }^{10}$ ISSF (International Seafood Sustainability foundation); 805 15th Street NW Suite 708 Washington DC 20005 ,USA

${ }^{11}$ IOTC (Indian Ocean Tuna Commission); Le Chantier Mall (2nd floor) PO Box 1011 Victoria

Mahé ,Seychelles

${ }^{12}$ Program of Fisheries and Aquatic Sciences; School of Forest Resources and Conservation;

University of Florida; PO Box 110410 Gainesville FL 32653 ,USA

* Corresponding author: Maite Pons, Tel.: +1 2068835102 ; Fax: +1 2066168689 ;

email address: mpons@uw.edu

\section{Abstract :}

Commercial tunas and billfishes (swordfish, marlins and sailfish) provide considerable catches and income in both developed and developing countries. These stocks vary in status from lightly exploited to rebuilding to severely depleted. Previous studies suggested that this variability could result from differences in life-history characteristics and economic incentives, but differences in exploitation histories and management measures also have a strong effect on current stock status. Although the status (biomass and fishing mortality rate) of major tuna and billfish stocks is well documented, the 
effect of these diverse factors on current stock status and the effect of management measures in rebuilding stocks have not been analysed at the global level. Here, we show that, particularly for tunas, stocks were more depleted if they had high commercial value, were long-lived species, had small prefishing biomass and were subject to intense fishing pressure for a long time. In addition, implementing and enforcing total allowable catches (TACs) had the strongest positive influence on rebuilding overfished tuna and billfish stocks. Other control rules such as minimum size regulations or seasonal closures were also important in reducing fishing pressure, but stocks under TAC implementations showed the fastest increase of biomass. Lessons learned from this study can be applied in managing large industrial fisheries around the world. In particular, tuna regional fisheries management organizations should consider the relative effectiveness of management measures observed in this study for rebuilding depleted large pelagic stocks.

Keywords: Fisheries management, marine conservation, stock assessment, stock status, tuna fisheries 
Table of Content:

\section{Introduction}

54 Methods

55 Data

56 Effect of different factors on the current biological status of major tuna and billfish stocks.

57 Effect of management regulations on depleted stocks.

58

59

60

61

62

63

64

65

66

67 The oceans have been subjected to intensive fishing pressure over the past 60 years, with

68

69

70

\section{Results and discussion}

Effect of different factors on the current biological status of major tuna and billfish stocks.

Effect of management regulations on depleted stocks.

\section{Acknowledgements}

\section{References}

\section{Supporting Information}

\section{Introduction} fisheries expanding to new geographic areas, shifting from coastal to pelagic environments (Swartz et al. 2010). As a result, an estimated 28-33\% of the large well-assessed fisheries of the world are overfished (Branch et al. 2011; FAO 2014), while many smaller unassessed fisheries 
in poorer countries are likely in worse shape (Costello et al. 2012). These depleted fisheries have negatively affected food security, fishing-dependent communities, and marine ecosystems globally (Scheffer et al. 2005).

Tunas and billfishes are important contributors to food security and income in both developed and developing countries and some of these stocks have experienced high exploitation rates for decades (Collette et al. 2011; Juan-Jordá et al. 2011; FAO 2014). While tunas and swordfish are the main target species of many fisheries, marlins are a common bycatch, particularly in commercial longline fisheries. Throughout the paper, 'tunas' were defined as the following commercially important species, often called the principal market tunas: southern bluefin (Thunnus maccoyii), Atlantic bluefin (T. thynnus), Pacific bluefin (T. orientalis), bigeye (T. obesus), albacore (T. alalunga), yellowfin (T. albacares), and skipjack (Katsuwonus pelamis). Also, 'Billfishes' includes not only marlins (Istiompax indica, Makaira nigricans, Kajikia albidus and $K$. audax) and sailfish (Istiophorus albicans) but also swordfish (Xiphias gladius).

A substantial proportion of these stocks has been categorized as overfished (Restrepo et al. 2003; Collette et al. 2011; Juan-Jordá et al. 2011; Punt et al. 2015). In 2003, catch-per-unit-effort data were used to suggest that industrial fishing pressure had reduced the abundance of tunas and billfishes (and other ocean predators) by 90\% from preindustrial levels (Myers and Worm 2003). More recent studies based on biomass trends estimated from stock assessment models found that tunas and their relatives had actually declined by an average of 60\% from unfished levels (JuanJordá et al. 2011), for which most stocks were above the biomass level that would produce 
maximum sustainable yield (MSY), and only a few were fished intensively enough to be classified as experiencing overfishing (Hampton et al. 2005; Polacheck 2006; Sibert et al. 2006).

Although the status of tunas and billfishes is well documented in the literature, the factors that drive the current status of these stocks are often not jointly analyzed. For example, life history strategies can affect the probability of stock collapse of many fish species (Reynolds et al. 2005). Tunas and billfishes range from small tunas and marlins with rapid growth rates and short lifespans to big tunas and swordfish with larger body sizes and longer lifespans (Fromentin and Fonteneau 2001; Juan-Jordá et al. 2012). Some tuna studies suggest that attributes such as short life span, wide geographic distribution, and opportunistic behavior make tropical tunas more productive and less susceptible to collapse than temperate tunas (Majkowski 2007; Collette et al. 2011; Juan-Jordá et al. 2011). Also, Sadovy (2001) suggested that, in long-lived species, the probability of extinction is related to limited geographical range, being part of mixed-species fisheries, or being distributed mainly in areas of intense fishing activity.

Moreover, economic factors may be equally or more important in determining stock status. Fishery profits, and not the trophic levels and associated characteristics of the target species, were found to be the dominant driver of historical fishery development patterns in a study that covered a wide range of stocks (Sethi et al. 2010). High market values drive exploitation far below MSY biomass levels and have increased the risk of stock collapse (Collette et al. 2011). Notably, while Pacific bluefin tuna and albacore tuna are both temperate species, albacore is used mostly for the cheaper canned tuna market, while Pacific bluefin serves the high-end 
115 sashimi market (Majkowski 2007). It may therefore not be surprising that Pacific bluefin is

116 overfished, while some albacore stocks are not.

118 In addition to life history and economic value, exploitation history and management measures

119 drive the status of tuna and billfish resources. Exploitation history is an important factor

120 affecting the conservation status of many exploited stocks (Melnychuk et al. 2013; Neubauer et

121 al. 2013) including tuna species. Atlantic bluefin tuna has been fished in the Mediterranean since

122 the 7th century $\mathrm{BC}$ and reconstructed bluefin tuna trap catches date back to the 16th century

123 (Fromentin and Powers 2005). On the other hand, skipjack and yellowfin tuna in the Indian

124 Ocean were not targeted until the development of large-scale commercial purse-seine fisheries in

125 the 1980s (Parks 1991), and these stocks are currently considered to be healthy (Juan-Jordá et al.

126 2011). In general, the development of commercial fisheries started earlier for species that were

127 easily accessible, abundant and valuable and then expanded to less valuable species (Sethi et al.

128 2010).

129

130 We also expect that highly regulated stocks are those that have been experiencing overfishing,

131 where strict management measures are placed to rebuild them, while stocks that lack strong

132 regulations are more often not overexploited. Tuna and billfish stocks are managed by tuna

133 Regional Fisheries Management Organizations (tRFMOs), including: International Commission

134 for the Conservation of Atlantic Tunas (ICCAT), Indian Ocean Tuna Commission (IOTC), Inter-

135 American Tropical Tuna Commission (IATTC), Western and Central Pacific Fisheries

136 Commission (WCPFC), and Commission for the Conservation of Southern Bluefin Tuna

137 (CCSBT). As an example, international management has clearly failed to keep some bluefin tuna 
stocks near target reference points despite their high commercial value (Fromentin and Powers 2005; Worm et al. 2009), and the ability of tRFMOs to prevent stock depletion and overfishing has been questioned (Cullis-Suzuki and Pauly 2010). The exploitation history and management actions taken vary greatly by tRFMO, and this may have a strong impact on the status of tuna and billfish stocks (Parma et al. 2006). Many tRFMOs have implemented a variety of input (or effort) controls, while others have implemented also output (or quota) controls.

Although there has been considerable discussion about what elements are required for successful fisheries management (Hilborn 2007; Beddington et al. 2007), the effectiveness of specific management measures for tunas and billfishes has not been analyzed on a global scale. The purpose of this paper is two-fold: 1) to evaluate the effect of different factors (management measures, life-history, economic values or exploitation history) on the current biological status of major tuna and billfish stocks of the world; and 2) to identify which management measures have promoted the recovery of depleted stocks.

\section{Methods}

In general, among tRFMOs, the stock status is summarized using two biological reference points, $B / B_{\mathrm{MSY}}$ (the current biomass, $B$, in relation to the $B$ that produces MSY) and $F / F_{\mathrm{MSY}}$ (the current fishing mortality, $F$, in relation to the $F$ that produces MSY). Thus, these reference points were considered in this study to define tuna and billfish stock status. Throughout the manuscript, we defined stocks as "overfished" if the biomass was reduced to a level less than what would provide MSY ( $\left.B<B_{\mathrm{MSY}}\right)$ and "overfishing" if the stock is subjected to a fishing mortality rate 
161 greater than that expected to produce the MSY $\left(F>F_{\mathrm{MSY}}\right)$. Stocks that had $B>B_{\mathrm{MSY}}$ and $F<F_{\mathrm{MSY}}$

162 were considered "healthy".

163

164 Data

165

166 Data used to assess the status of tunas and billfishes were obtained from stock assessment

167 outputs compiled in the RAM Legacy Stock Assessment Database (Ricard et al. 2012). Most

168 reference points time series available from assessments were current through 2012 . We found

169 data for 40 stocks of 13 species, 7 species of major commercial tunas and 6 species of billfishes

170 (Fig. S1-S2) from at least 48 stocks defined globally (Table 1).

171

172 Data for management variables were compiled from information available on the websites and

173 reports of different tRFMOs and through personal communication with their staff. Only

174 regulations that existed during the 5-10 year period leading up to the last stock assessment were

175 considered for each stock, although in some cases new management measures are currently in

176 place. Table 2 summarizes all management measures in place by stock and Table S1 lists the

177 relevant web references.

178

179

Effect of different factors on the current biological status of major tuna and billfish stocks

180

181 To evaluate our first objective in analyzing which factors can predict the biological status of tuna

182 and billfish stocks, we assessed the effect and importance of each predictor (Fig. S3) on the

183 geometric mean of the last 10 years of each time series of the two stock performance measures 
considered ( $B / B_{\mathrm{MSY}}$ and $\left.F / F_{\mathrm{MSY}}\right)$ using a random forest analysis (Breiman 2001). This approach was used previously to analyze similar data (Melnychuk et al. 2013) and has been increasingly used in ecology and fisheries studies (Lennert-Cody and Berk 2007; Gutiérrez et al. 2011). The main advantages of this method are that the non-parametric approach does not assume any particular distribution of error, it allows the use of many predictors in relation to the total number of observations, and it allows for visualization of non-linear relationships. It is an ensemble method that aggregates $K$ trees (forming the forest), each tree similar to ones constructed with CART (Classification and Regression Trees), and grown using a bootstrapped sample of the original data set. Each tree in the forest uses at each node only a number of variables randomly sampled as candidates from a subset of the explanatory variables (mtry), which in our case was equal to a third of the predictor variables (Liaw and Wiener 2002). To stabilize the mean square error, we used 10,000 trees. We used the 'randomForest' package (version 4.6-7) (Liaw and Wiener 2002) in R (version 3.0.1) (R Core Team 2014) for this analysis. We presented variable importance plots for both performance measures as the decrease in mean accuracy resulting from the removal of each variable, and presented partial dependence plots to show the effect of the main continuous predictors on the response variables (Liaw and Wiener 2002). We showed the results of partial dependence plots for tunas and billfishes independently, to show differences between these taxonomic groups, as well as combined.

The predictors considered (Fig. S3) include:

1. Taxa (factor): consisting of two categories, tunas or billfishes.

2. Year of fishery development (continuous): defined as the first year in which the total catch reached $25 \%$ of the maximum historical catch for the full time series available since 1950 . 
Those stocks with a maximum catch in 1950 were considered as developed in this year, although we know that some of them developed earlier (Sethi et al. 2010). Catch data do not necessarily include discards, unregulated artisanal catches or illegal, unreported and unregulated (IUU) catches.

3. Maximum sustainable yield (MSY, continuous): used on a log scale as a measure of the size of each stock.

4. Generation Time (GT, continuous): we used the values estimated by Collette et al. (2011) on a $\log$ scale as a biological predictor, because life history parameters such as growth, longevity and age of maturity are considered to be uncertain for most stocks of billfishes, if available (Kopf et al. 2009). In the supplemental material of Collette et al. (2011) there is a detailed explanation of how GT was calculated for each stock and/or species. The range of this variable is from 1 year for skipjack to 17.2 years for southern bluefin tuna (Table S2).

5. Market price (continuous): we obtained market price for tunas and billfishes from different sources. For all tunas stocks we used the data available in the FAO economic trade and markets database. However, for billfishes, detailed information by species was not available in this database. Therefore, US market price database for all billfish stocks was considered. In all cases, we used the average price for the last 10 years, from 2003 to 2012. Prices range from $\$ 0.96$ dollars $/ \mathrm{kg}$ for skipjack tuna to $\$ 14.49$ dollars $/ \mathrm{kg}$ for Southern bluefin tuna (Table S3).

6. Number of countries fishing each stock (continuous): we considered the smallest number of countries that cumulatively reported more than $75 \%$ of the total catch during the past 10 years (2003-2012) as a measure of how the total catch for each stock is allocated among countries (Table 2). 
7. Total allowable catch (TAC in years, continuous): this was used to take into account the number of years under TAC enforcement. We used a continuous variable ranging from 0 for stocks with no TACs to 31 for western Atlantic bluefin tuna. TACs have been set and enforced for almost all Atlantic tuna stocks and southern bluefin tuna, although for some of them there have been problems with underreporting of catches (Polacheck and Davies 2008; Polacheck 2012). A quota was implemented for white and blue marlins, as well as Pacific bluefin tuna in 2013, but we did not consider these species as having a quota in this study, since it is too early to see the effects of this measure on stock status (Table 2).

8. Input management measures were also considered (factor: presence/absence):

a) seasonal closures, for specific areas and seasons;

b) minimum size regulations, such as limits in captured length for some species;

c) fishing capacity limits, for some stocks ICCAT refers to limits in the number of vessels that can be also interpreted as a limit in fishing capacity. The only tRFMO that specifically refers to 'non-increase or reduction in fishing effort' is the WCPFC, but this is measured as number of licenses authorized so, it can be interpreted also as limits in fishing capacity;

d) catch restrictions, caps in relation to some previous catch level, but not as a formal TAC derived from a stock assessment (i.e., catch should not exceed some average historical level).

Some of the stocks, such as the two stocks of Atlantic bluefin tuna, are currently under a formal rebuilding plan that includes at least one of these input measures or a combination of them. In addition, some of the management measures in place can affect several stocks. For example, seasonal closures of purse seine fisheries in the Atlantic Ocean for bigeye tuna also affect the 
253 yellowfin tuna stock (Table 2), In this case, both stocks were considered as having seasonal 254 closures.

256 Before conducting random forest analyses, predictors were tested for collinearity using variance 257 inflation factors (VIF) (see supporting information, Table S4). In addition, we presented in the 258 main text the results from the average of the 10 years leading up to the last assessment for both 259 performance measures $\left(B / B_{\mathrm{MSY}}\right.$ and $\left.F / F_{\mathrm{MSY}}\right)$. However, we also considered the last year assessed 260 and a period of 5 years leading up to the last assessment for sensitivity analyses in the random 261 forest analysis finding that the results were not sensitive to the period of time selected (Fig. S4).

Effect of management regulations on depleted stocks

The same type of statistical analysis was used to identify which management measures have the strongest effect on the recovery of previously depleted stocks. We selected those stocks that

267 showed $B<B_{\mathrm{MSY}}$ or $F>F_{\mathrm{MSY}}$ ten years before the final assessment year. We used as a response variable the geometric mean of the annual rate of change of $B$ and $F$ during this period. We considered biomass levels increasing towards $B_{\mathrm{MSY}}$ and fishing mortality rates decreasing

270 towards $F_{\text {MSY }}$ as positive signs of stock rebuilding. The same input and output management 271 measures as in the previous analysis were used as predictors.

We conducted two sensitivity analyses, one removing the bluefin tuna stock from the eastern Atlantic, since it is an outlier in the rate-of-change data (Fig. S5), and another one removing the western Atlantic bluefin tuna stock, since it has 31 years of TAC implementation and could bias 
276 the results. In terms of variable importance, removing these data did not change the main results

277 observed using the complete dataset (Fig. S6).

\section{Results and Discussion}

We collected stock assessment information for 22 tunas and 18 billfish stocks covering all oceans (Fig. 1). There are still some billfishes, such as longbill, Mediterranean, roundscale and shortbill spearfishes, that remain unassessed because they are not commercially important species. These species cannot easily be assessed, since their catch statistics are generally aggregated with other species (Punt et al. 2015).

Tuna catches increased steadily from 1950-2000 and then stabilized in the last 10 years (Fig.

288 2a), with greatest catches coming from skipjack, particularly from the Western and Central

289 Pacific Ocean, followed by yellowfin, bigeye, albacore, and bluefin. Billfish catches also

290 increased before declining in recent years (Fig. 2b). The most important billfish stock by volume

291 during the 1950-1960s was Pacific blue marlin, while swordfish presently dominate catches in all

292 oceans. However, it should be noted that, because most marlin and sailfish stocks are

293 overexploited, some of these stocks can no longer be retained, and some artisanal catches remain 294 under- or unreported. In general, tunas have sustainable biomass and fishing mortality rates, with a median $B / B_{\mathrm{MSY}}$ of

2971.12 and $F / F_{\text {MSY }}$ of 0.81 (Fig. 2c). Bluefin tuna in the western Atlantic and southern bluefin tuna 298 are not showing signs of overfishing $\left(F<F_{\mathrm{MSY}}\right)$, but they are still overfished $\left(B<B_{\mathrm{MSY}}\right)$ due to past 
overexploitation. Pacific bluefin tuna and bigeye tuna in the West and Central Pacific Ocean are still experiencing overfishing with mortality rates exceeding $1.5 F_{\mathrm{MSY}}$ (Fig. 2c), although substantial management measures have recently been adopted for Pacific Bluefin (ISC 2014b). Overall, $64 \%$ of tuna stocks have healthy biomass levels, with $B$ above $B_{\mathrm{MSY}}$.

Billfishes are in slightly worse shape than tunas (Fig. 2d), with a median $B / B_{\mathrm{MSY}}$ of 0.85 and $F / F_{\mathrm{MSY}}$ of 1.01. Sailfish in the eastern and western Atlantic Ocean, and Atlantic blue marlin, are experiencing the highest exploitation rates (with $F>1.5 F_{\mathrm{MSY}}$ ), while swordfish in the eastern Pacific and Indian Ocean are above target biomass levels (Fig. 2d). For billfishes, only $39 \%$ have healthy biomass levels and $22 \%$ are still experiencing overfishing.

Overall, most tunas and billfish stocks are in healthy conditions, neither overfished nor subject to excessive fishing pressure. However, $23 \%$ of tunas and billfish stocks are still experiencing overfishing and the four stocks of most concern are both heavily depleted $\left(B<0.5 B_{\mathrm{MSY}}\right)$ and have high fishing mortality rates $\left(F>F_{\mathrm{MSY}}\right)$. These stocks are Pacific bluefin tuna, eastern and western Atlantic sailfish, and Atlantic blue marlin.

\section{Effect of different factors on the current biological status of major tuna and billfish stocks.}

In general, the status of tuna and billfish stocks is the product of diverse exploitation histories, biological characteristics, economic incentives, and management strategies (Fig. 3). The most important predictor variables affecting both performance measures were MSY and market price. The year of fishery development also affected the $F / F_{\mathrm{MSY}}$ ratio and the implementation of quotas 
322 the $B / B_{\mathrm{MSY}}$ ratio (Fig. 3). Overall, depletion was greater for less abundant and highly marketable

323 stocks that were subjected to intense fishing pressure for a long time. For both tunas and

324 billfishes, larger stocks had higher values of $B / B_{\mathrm{MSY}}$ and lower values of $F / F_{\mathrm{MSY}}$ than smaller

325 stocks. Later-developing fisheries had lower values of $F / F_{\mathrm{MSY}}$ than earlier-developing fisheries

326 and although not significant, higher values of $B / B_{\mathrm{MSY}}$ (Fig. 4). The same pattern was observed in

327 the western north American groundfish fisheries (Melnychuk et al. 2013).

329 Tunas and billfishes showed opposite influences of GT and market price. For tunas, higher

330 market price and longer GT were associated with higher rates of overfishing (higher $F / F_{\mathrm{MSY}}$ ).

331 Regarding the trends in biomass, a lower $B / B_{\mathrm{MSY}}$ was observed for highly valuable tunas,

332 however, the trend for GT was not as clear (Fig. 4). On the contrary, for billfishes, lower market

333 price and shorter GT were associated with higher $F / F_{\mathrm{MSY}}$ and lower $B / B_{\mathrm{MSY}}$ (Fig. 4 ). These

334 differences could be because billfishes, except for swordfish, are typically bycatch species and

335 not primary targets of industrial tuna fisheries, and therefore might not respond in the same way

336 to market price (Gentner 2007). In addition, marlins have shorter GT compared to swordfish and

337 nevertheless they showed higher fishing pressure. This is probably not associated directly to GT

338 but to the fact that marlins have a more restricted distribution, with much smaller population

339 sizes by far smaller than swordfish and can endure lower fishing mortality. Also, unlike on land,

340 Pinsky et al. (2011) suggested that long-lived marine fish species have a lower probability of

341 collapse than short-lived species, although there are certainly exceptions to this overall pattern. 
345 Twelve stocks (30\%) had no management measures in place in the last 10 year period (Table 2).

346 The other 28 stocks had at least one management measure in place during the past 10 years. Most

347 of these 28 stocks are under input management measures to control fishing mortality, such as

348 seasonal closures, minimum size regulations, input limitations on catch and/or fishing capacity.

349 Only eight stocks have a formal TAC and, except for southern bluefin tuna, all of the stocks are

350 managed by ICCAT (Table 2).

352 Fisheries under different types of management differed in status: TAC-managed fisheries had

353 low biomass and high fishing mortality; input-controlled fisheries had a wide range of biomass

354 and fishing mortality; and those with no management measures generally had high biomass and

355 low mortality rates (Fig. 5a-b). Notably, TACs generally have been implemented on less

356 abundant stocks that are already overfished (Fig. 5a-b). For example, the eastern and western

357 stocks of Atlantic bluefin tuna have been managed with TACs for 15 and $>30$ years,

358 respectively. However, the effect of the TAC implementation on these stocks could be more

359 recent because ICCAT did not follow the scientific advice at the begging and recommended

360 catches that exceeded the scientific recommendations (Fromentin et al. 2014). When we take a

361 look at the rate of change over the last 10 years, the biomass of TAC-managed stocks is

362 increasing, and fishing mortality is declining, unlike those managed by input controls or with no

363 controls (Fig. 5c-d).

364

365 Using a random forest analysis, we identified management measures influencing the recovery of

366 stocks that were below $B_{\mathrm{MSY}}\left(17\right.$ stocks) or were experiencing fishing mortality above $F_{\mathrm{MSY}}(19$

367 stocks) 10 years before the last assessment. We found that previously-depleted tuna and billfish 
stocks that were under some type of management measure showed improvements over the 10year period leading up to the last stock assessment, with biomass increasing and fishing mortality decreasing over time (Fig. S4). Of all management measures considered, the number of years since TAC implementation had the strongest effect on stock rebuilding, especially on increasing biomass, but also to some extent on decreasing fishing mortality (Fig. 6), as expected from other studies showing the impact of catch limits (Melnychuk et al. 2012; Neubauer et al. 2013; Hilborn and Ovando 2014). Although not possible to determine from our analyses, the success of quotas over other management measures may simply be that quotas result from a more serious effort to manage a stock. While TACs were most important in rebuilding biomass, and did decrease fishing mortality, input management measures such as minimum size regulations and seasonal closures were also important in reducing fishing mortality (Fig. 6), as was suggested particularly for the eastern Atlantic bluefin tuna stock (Fromentin et al. 2014). In particular for IOTC stocks, one possible confounding effect regarding the reduction in fishing mortality could be associated with Somali piracy in the Western Indian Ocean starting 2007 (Dueri et al. 2014). This could be considered as a controversial spatial closure that it was not taken into account in this study.

We plotted changes in status for stocks that were below target reference levels $\left(\mathrm{B}<\mathrm{B}_{\mathrm{MSY}}\right.$ and $\left.F>F_{\text {MSY }}\right) 10$ years before the last assessment, highlighting stocks with and without TACs (Fig. 7) to show the change in status. Stocks with TACs showed a decrease in fishing mortality (arrows moving from the upper left to the lower left quadrant) and an increase in biomass (arrows moving from the left to the right) (Fig. 7). This is a clear signal of rebuilding; fishing mortality is reduced and thus biomass increases. Although fishing mortality was reduced for most stocks 
without TACs, most of these stocks still show a decrease in biomass, consistent with the results

392 from the random forest analysis (Fig. 6).

Only ICCAT and CCSBT have applied TACs for regionally-managed tuna and billfish stocks. National TACs have been proposed as a possible method to harvest resources in the Eastern Pacific Ocean, but there is a debate among IATTC scientists and managers about how such a quota should be allocated. This tRFMO faces different obstacles to the adoption of allocation systems for tropical tuna fisheries because of the lack of clarity regarding which criteria to apply for assigning fishing rights in light of the considerable heterogeneity of the participants in the fishery (Allen 2010). However, IATTC implemented a TAC of 5,000 t for Pacific bluefin tuna in 2014, although the success of this measure remains to be seen. ICCAT also implemented quotas on yellowfin tuna and blue and white marlin in 2012 (Table 2).

403 Input management measures are relatively easy to implement, but difficult to enforce without an appropriate monitoring and surveillance system (Cochrane and Garcia 2009). Also, effort regulations can be affected by "effort creep" and uncertainty in the relationship between fishing

408 circumvented by underreporting or illegal fishing, if they are not effectively enforced by 409 authorities. Catches reported to tRFMOs that applied TACs seldom exceed target TACs

410 (Fromentin et al. 2014). However, ICCAT has suggested that bluefin catches from the eastern 411 Atlantic and Mediterranean were seriously underreported from 1998 to 2007 and the CCSBT has 412 found evidence that Southern bluefin catches may have been substantially underreported since at 413 least the early 1990s (Polacheck 2012). The latest Atlantic bluefin tuna stock assessments took 
414 underreporting into account, and underreporting is thought to have declined in recent years in

415 these fisheries (ICCAT 2015a).

416

417 Lessons learned from managing tuna and billfish can be applied to manage other large industrial

418 fisheries. Large targeted stocks that receive direct management attention are generally better

419 managed than small stocks that are caught incidentally, like marlins and sailfish. When fisheries

420 management is weak, high-value species such as bluefin and bigeye tuna are the most likely to

421 be overexploited. Strong management measures such as TACs could prevent the overexploitation

422 of these species, but TACs have not typically been applied until stocks are heavily overfished

423 (Fig. 5a). On the other hand, TACs alone are, in some cases, insufficient to ensure sustainable

424 fisheries. For example, overexploitation of bigeye tuna is in part due to the bycatch of small

425 individuals by purse seiners targeting other tuna species, i.e., skipjack and yellowfin. So, other

426 management measures such as seasonal closures or minimum size regulations are also needed to

427 protect this part of the population and avoid overfishing.

429 Can these lessons about tuna be applied elsewhere? In many regions and fisheries, TACs are not

430 easy to apply, particularly where fleets are small, diverse, and target a range of species. In such

431 fisheries, other management tools may be more appropriate (Worm et al. 2009; Gutiérrez et al.

432 2011) Input controls, for instance, may have a higher probability of being accepted by the

433 fishing industry. Nevertheless, where applicable, TACs should be considered as a primary tool

434 for managing depleted stocks as they could lead to faster stock rebuilding. This can be explore

435 using approaches like Management Strategy Evaluation (MSE) to examine both input (effort)

436 and output (catch quota) controls in each fishery (Carruthers et al. 2014). 
Acknowledgments: This project was funded by the Pelagic Fisheries Research Program of the Joint Institute for Marine and Atmospheric Research, and the Walton Family Foundation. MP was supported by a Fulbright Fellowship.

We thank Carolina Minte-Vera and Alexandre Da-Silva for making some of the IATTC stock assessment data available to update the RAM Legacy database. Also, we thank Tom Nishida, Freddy Arocha, Adam Langley, Dale Kolody, Alec MacCall, Steven Teo and Michael Hinton for their comments during the design of the study, and Wataru Tanoue and Andrés Domingo for their comments on the initial draft of the manuscript.

\section{References}

Aires-da-Silva, A. and Maunder, M.N. (2014) Status of Bigeye tuna in the Eastern PAcific Ocean in 2013 and outlook for the future. Inter-American Tropical Tuna Commission Report, 1-12.

Allen, R. (2010) International management of tuna fisheries: arrangements, challenges and a way forward. Food and Agriculture Organization, Rome.

Beddington, J.R., Agnew, D.J. and Clark, C.W. (2007) Current Problems in the Management of Marine Fisheries. Science (New York, N.Y.) 316, 1713-6.

Branch, T.A., Jensen, O.P., Ricard, D., Ye, Y. and Hilborn, R. (2011) Contrasting Global Trends in Marine Fishery Status Obtained from Catches and from Stock Assessments. Conservation Biology 25, 777-786.

Breiman, L.E.O. (2001) Random Forests. Machine Learning 45, 5-32.

Carruthers, T.R., Punt, A.E., Walters, C.J., MacCall, A., McAllister, M.K., Dick, E.J. and Cope, J. (2014) Evaluating methods for setting catch limits in data-limited fisheries. Fisheries Research 153, 48-68.

CCSBT (2014) Report of the Nineteenth Meeting of the Scientific Committee. The Commission for the Conservation of Southern Bluefin Tuna, 1-115.

Cochrane, K.L. and Garcia, S. (2009) A Fishery Manager's Guidebook. The Food and Agriculture Organization, Rome.

Collette, B.B., Carpenter, K.E., Polidoro, B.A., et al. (2011) High Value and Long Life-Double Jeopardy for Tunas and Billfishes. Science (New York, N.Y.) 333, 291-292.

Costello, C., Ovando, D., Hilborn, R., Gaines, S.D., Deschenes, O. and Lester, S.E. (2012) Status 
and solutions for the world's unassessed fisheries. Science (New York, N.Y.) 338, 517-20.

Cullis-Suzuki, S. and Pauly, D. (2010) Failing the high seas: A global evaluation of regional fisheries management organizations. Marine Policy 34, 1036-1042.

Davies, N., Harley, S.J., Hampton, J. and McKechnie, S. (2014) Stock assessment of Yellowfin tuna in the Western and Central Pacific Ocean. Western and Central Pacific Fisheries Commission (WCPFC) Report, 1-119.

Davies, N., Hoyle, S.D. and Hampton, J. (2012) Stock Assessment of Striped Marlin (Kajikia audax) in the Southwest Pacific Ocean. Western and Central Pacific Fisheries Commission Report, 1-84.

Davies, N., Pilling, G., Harley, S.J. and Hampton, J. (2013) Stock assessment of swordfish (Xiphias gladius) in the Southwest Pacific Ocean. Western and Central Pacific Fisheries Commission (WCPFC) Report, 1-79.

Dueri, S., Kaplan, D.M., Chassot, E., Amande, J.M., Dagorn, L. and Fonteneau, A. (2014) fisheries : potential and perspectives.

FAO (2014) The State of World Fisheries and Aquaculture 2014. Food and Agriculture Organization, Rome.

Fromentin, J.M., Bonhommeau, S., Arrizabalaga, H. and Kell, L.T. (2014) The spectre of uncertainty in management of exploited fish stocks: The illustrative case of Atlantic bluefin tuna. Marine Policy 47, 8-14.

Fromentin, J.M. and Fonteneau, A. (2001) Fishing effects and life history traits: a case study comparing tropical versus temperate tunas. Fisheries Research 53, 133-150.

Fromentin, J.-M. and Powers, J.E. (2005) Atlantic bluefin tuna : population dynamics , ecology, fisheries and management. Fish and Fisheries 6, 281-306.

Gentner, B. (2007) Economic Analysis of International Billfish Markets. Gentner Consulting Group, Maryland.

Gutiérrez, N.L., Hilborn, R. and Defeo, O. (2011) Leadership, social capital and incentives promote successful fisheries. Nature 470, 386-9.

Hampton, J., Sibert, J.R., Kleiber, P., Maunder, M.N. and Harley, S.J. (2005) Fisheries: decline of Pacific tuna populations exaggerated? Nature 434, E1-E2.

Harley, S.J., Davies, N., Hampton, J. and McKechnie, S. (2014) Stock assessment of Bigeye tuna in the Western and Central Pacific Ocean. Western and Central Pacific Fisheries Commission (WCPFC) Report, 1-115.

Hilborn, R. (2007) Moving to Sustainability by Learning from Successful Fisheries. Ambio 36, 296-303.

Hilborn, R. and Ovando, D. (2014) Reflections on the success of traditional fisheries management. ICES Journal of Marine Science 71, 1040-1046.

Hinton, M.G. and Maunder, M.N. (2010) Status and Trends of Striped Marlin in the Northeast Pacific Ocean in 2009. Inter-American Tropical Tuna Commission Report, 163-218. 
Hinton, M.G. and Maunder, M.N. (2011a) Status of Sailfish in the Eastern Pacific Ocean in 2011 and Outlook for the Future. Inter-American Tropical Tuna Commission Report, 224-251.

Hinton, M.G. and Maunder, M.N. (2011b) Status of swordfish in the eastern Pacific Ocean in 2010 and outlook for the future. Inter-American Tropical Tuna Commission Report, 1-33.

Hoyle, S.D., Hampton, J. and Davies (2012) Stock assessment of Albacore tuna in the South Pacific Ocean. Western and Central Pacific Fisheries Commission (WCPFC) Report, 1123.

Hoyle, S.D., Sharma, R. and Herrera, M. (2014) Stock assessment of albacore tuna in the Indian Ocean for 2014 using Stock Synthesis. Indian Ocean Tuna Commission Report, 1-74.

ICCAT (2009) Report of the 2008 ICCAT Yellowfin and Skipjack Stock Assessments Meeting. Collective Volume of Scientific Papers ICCAT 64, 669-927.

ICCAT (2010a) Report of the 2009 Sailfish stock assessment. Collective Volume of Scientific Papers ICCAT 65, 1507-1632.

ICCAT (2010b) Report of the 2010 ICCAT bigeye tuna stock assessment session. Collective Volume of Scientific Papers ICCAT 66, 187-284.

ICCAT (2011) Report of the 2010 ICCAT Mediterranean swordfish stock assessment meeting. Collective Volume of Scientific Papers ICCAT 66, 1405-1470.

ICCAT (2012a) Report of the 2011 Blue marlin stock assessment and White marlin data preparatory meeting. Collective Volume of Scientific Papers ICCAT 68, 1273-1386.

ICCAT (2012b) Report of the 2011 ICCAT South Atlantic and Mediterranean Albacore stock assessment sessions. Collective Volume of Scientific Papers ICCAT 68, 387-497.

ICCAT (2012c) Report of the 2011 ICCAT Yellowfin Tuna stock assessment session. Collective Volume of Scientific Papers ICCAT 68, 655-817.

ICCAT (2013) Report of the 2012 White marlin stock assessment meeting. Collective Volume of Scientific Papers ICCAT 69, 1085-1183.

ICCAT (2014a) Report of the 2013 Atlantic Swordfish stock assessment session. Collective Volume of Scientific Papers ICCAT 70, 1484-1678.

ICCAT (2014b) Report of the 2013 ICCAT North and South Atlantic Albacore stock assessment meeting. Collective Volume of Scientific Papers ICCAT 70, 830-995.

ICCAT (2015a) Report of the 2014 Atlantic Bluefin tuna stock assessment session. Collective Volume of Scientific Papers ICCAT 71, 692-945.

ICCAT (2015b) Report of the 2014 ICCAT East and West Atlantic Skipjack stock assessment meeting. Collective Volume of Scientific Papers ICCAT 71, 1-172.

ISC (2014a) North Pacific swordfish (Xiphias gladius) stock assessment in 2014. Draft report of the billfish working group. International Scientific Committee for Tuna and Tuna-like Species in the North Pacific Ocean Report, 1-87.

ISC (2014b) Stock Assessment for Pacific Bluefin Tuna in 2014. International Scientific Committee for Tuna and Tuna-like Species in the North Pacific Ocean Report, 1-121. 
ISC (2014c) Stock Assessment of Albacore Tuna in the North Pacific Ocean in 2014. International Scientific Committee for Tuna and Tuna-like Species in the North Pacific Ocean Report, 1-131.

ISC (2013) Stock Assessment of blue marlin in the Pacific Ocean in 2013. Western and Central Pacific Fisheries Commission Report, 1-123.

Juan-Jordá, M.J., Mosqueira, I., Cooper, A.B., Freire, J. and Dulvy, N.K. (2011) Global population trajectories of tunas and their relatives. Proceedings of the National Academy of Sciences of USA 108, 20650-20655.

Juan-Jordá, M.J., Mosqueira, I., Freire, J. and Dulvy, N.K. (2012) Life in 3-D: life history strategies in tunas, mackerels and bonitos. Reviews in Fish Biology and Fisheries 23, 135155.

Kopf, R.K., Drew, K. and Jr, R.L.H. (2009) Age estimation of billfishes (Kajikia spp.) using fin spine cross-sections: the need for an international code of practice. Aquatic Living Resources 23, 13-23.

Langley, A., Herrera, M. and Sharma, R. (2013) Stock assessment of bigeye tuna in the Indian Ocean for 2012 . Indian Ocean Tuna Commission Report, 1-36.

Lee, H.-H., Piner, K.R., Humphreys, R. and Brodziak, J. (2013a) Stock Assessment of Striped Marlin in the Western and Central North Pacific Ocean. International Scientific Committee for Tuna and Tuna-like Species in the North Pacific Ocean Report, 1-116.

Lee, S. Il, Lee, M.K., Lee, D. and Nishida, T. (2013b) Stock assessment on yellowfin tuna (Thunnus albacares) in the Indian Ocean by ASPIC and comparison to MULTIFAN-CL and ASPM. Indian Ocean Tuna Commission Report, 1-7.

Lennert-Cody, C.E. and Berk, R.A. (2007) Statistical learning procedures for monitoring regulatory compliance: an application to fisheries data. Journal of the Royal Statistical Society: Series A (Statistics in Society) 170, 671-689.

Liaw, A. and Wiener, M. (2002) Classification and Regression by randomForest. $R$ News $\mathbf{2}, 18-$ 22.

Majkowski, J. (2007) Review of the state of world marine fishery resources. FAO Fisheries Technical Paper No. 438 (FAO, Rome).

Maunder, M.N. (2011) Status of skipjack tuna in the Eastern Pacific Ocean in 2011. InterAmerican Tropical Tuna Commission Report, 33-60.

Melnychuk, M.C., Banobi, J.A. and Hilborn, R. (2013) Effects of Management Tactics on Meeting Conservation Objectives for Western North American Groundfish Fisheries. PLoS ONE 8, e56684.

Melnychuk, M.C., Essington, T.E., Branch, T.A., et al. (2012) Can catch share fisheries better track management targets? Fish and Fisheries 13, 267-290.

Minte-Vera, C. V., Aires-da-Silva, A. and Maunder, M.N. (2014) Status of yellowfin tuna in the eastern Pacific Ocean in 2013 and outlook for the future. Inter-American Tropical Tuna Commission Report, 1-15. 
Myers, R.A. and Worm, B. (2003) Rapid worldwide depletion of predatory fish communities. Nature 423, 280-283.

Neubauer, P., Jensen, O.P., Hutchings, J.A. and Baum, J.K. (2013) Resilience and Recovery of Overexploited Marine Populations. Science (New York, N.Y.) 340, 347-349.

Parks, W.W. (1991) A review of Indian Ocean fisheries for skipjack tuna, Katsuwonus pelamis, and yellowfin tuna, Thunnus albacares. Marine Fisheries Review 53, 1-9.

Parma, A.M., Hilborn, R. and Orensanz, J.M.L. (2006) The good, the bad, and the ugly: learning from experience to achieve sustainable fisheries. Bulletin of Marine Science 78, 411-427.

Pinsky, M.L., Jensen, O.P., Ricard, D. and Palumbi, S.R. (2011) Unexpected patterns of fisheries collapse in the world's oceans. Proceedings of the National Academy of Sciences of the USA 108, 8317-8322.

Polacheck, T. (2012) Assessment of IUU fishing for Southern Bluefin Tuna. Marine Policy 36, $1150-1165$.

Polacheck, T. (2006) Tuna longline catch rates in the Indian Ocean: Did industrial fishing result in a $90 \%$ rapid decline in the abundance of large predatory species? Marine Policy 30, 470 482.

Polacheck, T. and Davies, C. (2008) Considerations of the Implications of Large Unreported Catches of Southern Bluefin Tuna for Assessments of Tropical Tunas, and the Need for Independent Verification of Catch and Effort Statistics. CSIRO Marine and Atmospheric Research Paper 023.

Punt, A.E. and Donovan, G.P. (2007) Developing management procedures that are robust to uncertainty: lessond from the International Whaling Comimission. ICES Journal of Marine Science 64, 603-612.

Punt, A.E., Su, N.-J. and Sun, C.-L. (2015) Assessing billfish stocks: A review of current methods and some future directions. Fisheries Research 166, 103-118.

R Core Team (2014) R: A Language and Environment for Statistical Computing. Vienna, Austria.

Restrepo, V., Prince, E.D., Scott, G.P. and Uozumi, Y. (2003) ICCAT stock assessments of Atlantic billfish. Marine And Freshwater Research 54, 361-367.

Reynolds, J.D., Dulvy, N.K., Goodwin, N.B. and Hutchings, J.A. (2005) Biology of extinction risk in marine fishes. Proceedings. Biological sciences / The Royal Society 272, 2337-44.

Ricard, D., Minto, C., Jensen, O.P. and Baum, J.K. (2012) Examining the knowledge base and status of commercially exploited marine species with the RAM Legacy Stock Assessment Database. Fish and Fisheries 13, 380-398.

Rice, J., Harley, S., Davies, N. and Hampton, J. (2014) Stock assessment of skipjack tuna in the Western and Central Pacific Ocean. Western and Central Pacific Fisheries Commission (WCPFC) Report, 1-125.

Sadovy, Y. (2001) The threat of fishing to highly fecund fishes. Journal of Fish Biology 59, 90108. 
622 Scheffer, M., Carpenter, S. and de Young, B. (2005) Cascading effects of overfishing marine $623 \quad$ systems. Trends in ecology \& evolution 20, 579-581.

624 Sethi, S.A., Branch, T.A. and Watson, R. (2010) Global fishery development patterns are driven

625

626

627

628

629

630

631

632

633

634

635

636

637

638

639

640

641

642 by profit but not trophic level. Proceedings of the National Academy of Sciences of the USA 107, 12163-7.

Sharma, R. (2013) Stock assessment of three billfish species in Indian Ocean, blue, black and striped marlin using Stock Reduction Methods. Indian Ocean Tuna Commission Report, 123.

Sharma, R. and Herrera, M. (2014a) An Age,-sex- and spatially-structured stock assessment of the Indian Ocean Sworfish fishery 1950-2012, using stock synthesis. Indian Ocean Tuna Commission Report, 1-59.

Sharma, R. and Herrera, M. (2014b) Indian Ocean Skipjack Tuna Stock Assessment 1950-2011 (Stock Synthesis). Indian Ocean Tuna Commission Report, 1-78.

Sibert, J., Hampton, J., Kleiber, P. and Maunder, M. (2006) Biomass, Size, and Trophic Status of Top Predators in the Pacific Ocean. Science (New York, N.Y.) 314, 1773-1776.

Swartz, W., Sala, E., Tracey, S., Watson, R. and Pauly, D. (2010) The Spatial Expansion and Ecological Footprint of Fisheries (1950 to Present). PLoS ONE 5, e15143.

Worm, B., Hilborn, R., Baum, J.K., et al. (2009) Rebuilding Global Fisheries. Science (New York, N.Y.) 325, 578-85. 


\begin{tabular}{|c|c|c|c|c|c|c|c|}
\hline Species & Ocean & tRFMO & Stock common name & Code & $B / B_{\mathrm{MSY}}$ & $\boldsymbol{F} / \boldsymbol{F}_{\mathrm{MSY}}$ & Reference \\
\hline \multicolumn{8}{|l|}{ TUNAS } \\
\hline \multirow[t]{5}{*}{ Katsuwonus pelamis } & Pacific & WCPFC & $\begin{array}{l}\text { Skipjack tuna Central } \\
\text { Western Pacific }\end{array}$ & SKJ-WCPO & 1.71 & 0.62 & (Rice et al. 2014) \\
\hline & Atlantic & ICCAT & $\begin{array}{l}\text { Skipjack tuna Eastern } \\
\text { Atlantic }\end{array}$ & SKJ-E-AO & 1.708 & 0.27 & (ICCAT 2009) \\
\hline & Indian & IOTC & Skipjack tuna Indian Ocean & SKJ-IO & 1.15 & 0.62 & $\begin{array}{c}\text { (Sharma and Herrera } \\
2014 \mathrm{~b})\end{array}$ \\
\hline & Atlantic & ICCAT & $\begin{array}{l}\text { Skipjack tuna Western } \\
\text { Atlantic }\end{array}$ & SKJ-W-AO & 1.31 & 0.83 & (ICCAT 2015b) \\
\hline & Pacific & IATTC & $\begin{array}{l}\text { Skipjack tuna Eastern } \\
\text { Pacific Ocean }\end{array}$ & SKJ-EPO & \multicolumn{2}{|c|}{ No reference points } & (Maunder 2011) \\
\hline \multirow[t]{6}{*}{ Thunnus alalunga } & Indian & IOTC & Albacore tuna Indian Ocean & ALB-IO & 1.08 & 0.69 & (Hoyle et al. 2014) \\
\hline & Atlantic & ICCAT & $\begin{array}{l}\text { Albacore tuna } \\
\text { Mediterranean }\end{array}$ & ALB-MED & 1.91 & 0.99 & (ICCAT 2012b) \\
\hline & Atlantic & ICCAT & $\begin{array}{l}\text { Albacore tuna North } \\
\text { Atlantic }\end{array}$ & ALB-N-AO & 0.76 & 0.75 & (ICCAT 2014b) \\
\hline & Pacific & $\begin{array}{l}\text { WCPFC } \\
\text {-IATTC }\end{array}$ & Albacore tuna North Pacific & ALB-N-PO & 2.21 & 0.52 & (ISC 2014c) \\
\hline & Atlantic & ICCAT & $\begin{array}{l}\text { Albacore tuna South } \\
\text { Atlantic }\end{array}$ & ALB-S-AO & 0.84 & 1.09 & (ICCAT 2014b) \\
\hline & Pacific & WCPFC & $\begin{array}{l}\text { Albacore tuna South Pacific } \\
\text { Ocean }\end{array}$ & ALB-S-PO & 2.6 & 0.21 & (Hoyle et al. 2012) \\
\hline \multirow[t]{4}{*}{ Thunnus albacares } & Atlantic & ICCAT & Yellowfin tuna Atlantic & YFT-AO & 0.67 & 1.15 & (ICCAT 2012c) \\
\hline & Pacific & WCPFC & $\begin{array}{l}\text { Yellowfin tuna Central } \\
\text { Western Pacific }\end{array}$ & YFT-WCPO & 1.37 & 0.72 & (Davies et al. 2014) \\
\hline & Pacific & IATTC & $\begin{array}{l}\text { Yellowfin tuna Eastern } \\
\text { Pacific }\end{array}$ & YFT-EPO & 0.85 & 0.99 & $\begin{array}{l}\text { (Minte-Vera et al. } \\
\text { 2014) }\end{array}$ \\
\hline & Indian & IOTC & $\begin{array}{l}\text { Yellowfin tuna Indian } \\
\text { Ocean }\end{array}$ & YFT-IO & 1.15 & 0.61 & (Lee et al. 2013b) \\
\hline Thunnus maccoyii & Indian & CCSBT & Southern bluefin tuna & SBT & 0.23 & 0.76 & (CCSBT 2014) \\
\hline \multirow[t]{4}{*}{ Thunnus obesus } & Atlantic & ICCAT & Bigeye tuna Atlantic & BET-AO & 1.01 & 0.95 & (ICCAT 2010b) \\
\hline & Pacific & IATTC & Bigeye tuna Eastern Pacific & BET-EPO & 1.05 & 0.95 & $\begin{array}{l}\text { (Aires-da-Silva and } \\
\text { Maunder 2014) }\end{array}$ \\
\hline & Indian & IOTC & Bigeye tuna Indian Ocean & BET-IO & 1.20 & 0.79 & (Langley et al. 2013) \\
\hline & Pacific & WCPFC & $\begin{array}{l}\text { Bigeye tuna Western Pacific } \\
\text { Ocean }\end{array}$ & BET-WCPO & 0.94 & 1.57 & (Harley et al. 2014) \\
\hline Thunnus orientalis & Pacific & $\begin{array}{l}\text { WCPFC } \\
\text {-IATTC }\end{array}$ & $\begin{array}{l}\text { Pacific bluefin tuna Pacific } \\
\text { Ocean }\end{array}$ & PBF & 0.42 & 2.72 & (ISC 2014b) \\
\hline \multirow[t]{2}{*}{ Thunnus thynnus } & Atlantic & ICCAT & $\begin{array}{l}\text { Bluefin tuna Eastern } \\
\text { Atlantic }\end{array}$ & BFT-E-AO & 1.73 & 0.24 & (ICCAT 2015a) \\
\hline & Atlantic & ICCAT & $\begin{array}{l}\text { Bluefin tuna Western } \\
\text { Atlantic }\end{array}$ & BFT-W-AO & 0.48 & 0.85 & (ICCAT 2015a) \\
\hline \multicolumn{8}{|l|}{ BILLFISHES } \\
\hline \multirow[t]{4}{*}{ Xiphias galdius } & Pacific & IATTC & $\begin{array}{l}\text { Swordfish South Eastern } \\
\text { Pacific }\end{array}$ & SWO-EPO & 8.96 & 0.06 & $\begin{array}{c}\text { (Hinton and Maunder } \\
2011 \mathrm{~b} \text { ) }\end{array}$ \\
\hline & Indian & IOTC & Swordfish Indian Ocean & SWO-IO & 1.81 & 0.70 & $\begin{array}{c}\text { (Sharma and Herrera } \\
\text { 2014a) }\end{array}$ \\
\hline & Atlantic & ICCAT & $\begin{array}{l}\text { Swordfish Mediterranean } \\
\text { Sea }\end{array}$ & SWO-MED & 0.96 & 0.89 & (ICCAT 2011) \\
\hline & Atlantic & ICCAT & Swordfish North Atlantic & SWO-N-AO & 1.14 & 0.81 & (ICCAT 2014a) \\
\hline
\end{tabular}




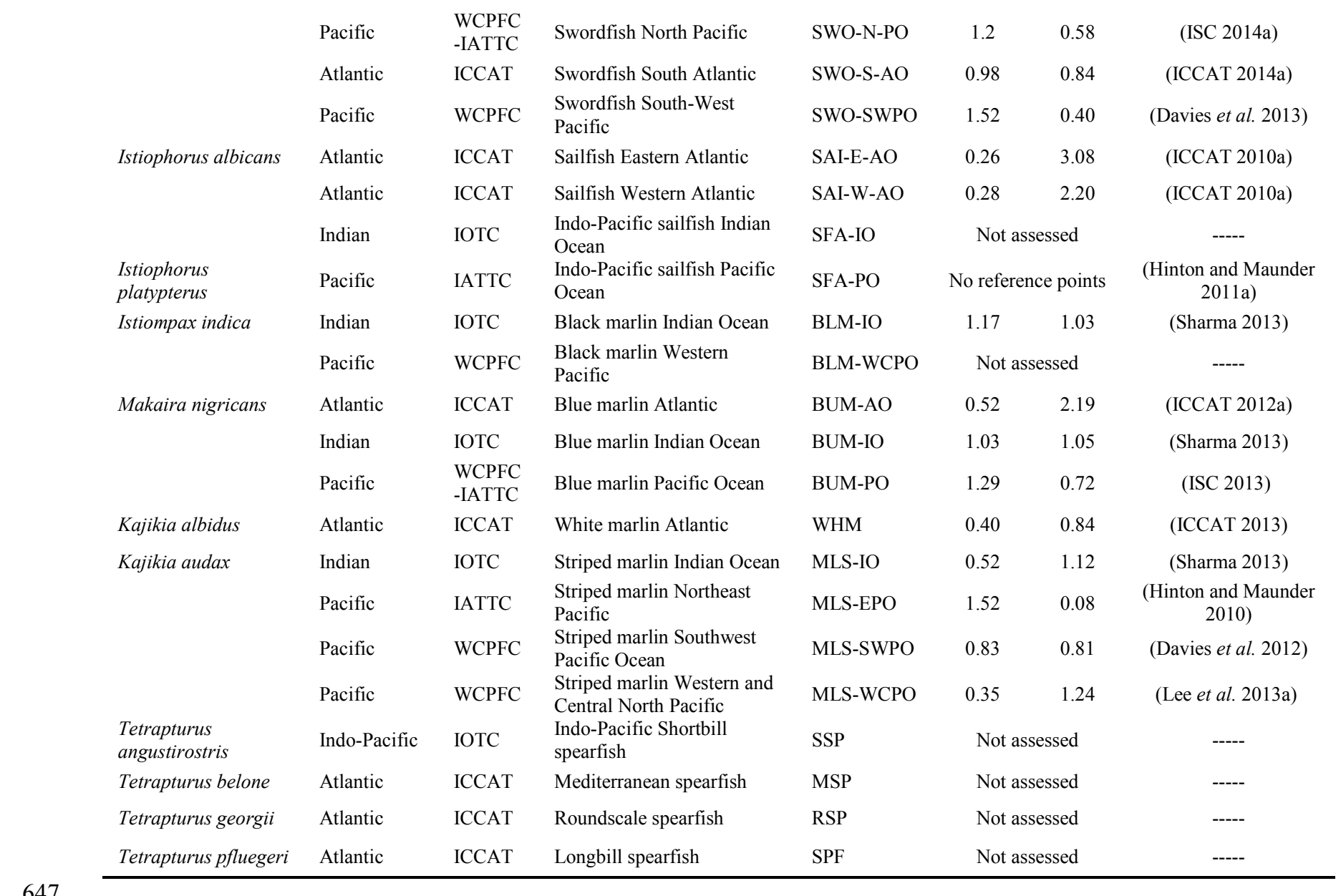


Table 2. Summary of management measures by stock. The stock codes are listed in Table 1.

\begin{tabular}{|c|c|c|c|c|c|c|c|c|c|}
\hline Code & $\begin{array}{l}\text { Year of } \\
\text { fishery } \\
\text { develop } \\
\text { ment }\end{array}$ & $\begin{array}{l}\text { \# } \\
\text { Countri } \\
\text { es } \\
\text { reporti } \\
\text { ng } \\
>75 \% \\
\text { catches }\end{array}$ & $\begin{array}{l}\text { Year of } \\
\text { formal } \\
\text { TAC } \\
\text { Implem } \\
\text { entatio } \\
\quad n\end{array}$ & $\begin{array}{l}\text { Season } \\
\text { al } \\
\text { closure } \\
\quad \mathrm{s}\end{array}$ & $\begin{array}{l}\text { Catch } \\
\text { restricti } \\
\text { ons, } \\
\text { other } \\
\text { than } \\
\text { TACs }\end{array}$ & $\begin{array}{l}\text { Minim } \\
\text { um size } \\
\text { regulati } \\
\text { ons }\end{array}$ & $\begin{array}{l}\text { Fishing } \\
\text { capacit } \\
\text { y limits }\end{array}$ & Description & $\begin{array}{l}\text { Reference to } \\
\text { Table } S 1 \text { in } \\
\text { the } \\
\text { supporting } \\
\text { information }\end{array}$ \\
\hline$\overline{\text { SBT }}$ & 1957 & 3 & 2006 & No & No & No & No & $\begin{array}{l}\text { Although voluntary quotas were put in } \\
\text { place in } 1985 \text { by the main fishing } \\
\text { countries at the time, the first global } \\
\text { TACs including all current CCSBT } \\
\text { members was agreed in } 2007 \text {. However, } \\
\text { starting in } 2006 \text { more effective TAC } \\
\text { compliance measures were } \\
\text { implemented. } \\
\text { In } 2011 \text { CCSBT adopted a formal } \\
\text { rebuilding plan for SBT.* }\end{array}$ & 1 \\
\hline $\begin{array}{l}\text { BET- } \\
\text { EPO }\end{array}$ & 1961 & 19 & $\begin{array}{l}\text { No } \\
\text { quota }\end{array}$ & Yes & No & No & Yes & $\begin{array}{l}\text { IATTC C-02-03, reduction in fishing } \\
\text { capacity in purse-seine fisheries; C-02- } \\
04, \mathrm{C}-03-12, \mathrm{C}-04-09, \mathrm{C}-10-01, \mathrm{~A} \\
\text { seasonal closure of the purse seine } \\
\text { fishery in an area known as "El } \\
\text { Corralito", near Galapagos. C-13-01, } \\
\text { annual catch limits. * }\end{array}$ & $2-7$ \\
\hline $\begin{array}{l}\text { MLS- } \\
\text { EPO }\end{array}$ & 1962 & 16 & $\begin{array}{l}\text { No } \\
\text { quota }\end{array}$ & No & No & No & No & No management measures in effect. & \\
\hline $\begin{array}{l}\text { SWO- } \\
\text { EPO }\end{array}$ & 1987 & 18 & $\begin{array}{l}\text { No } \\
\text { quota }\end{array}$ & No & No & No & No & No management measures in effect & \\
\hline $\begin{array}{l}\text { YFT- } \\
\text { EPO }\end{array}$ & 1950 & 19 & $\begin{array}{l}\text { No } \\
\text { quota }\end{array}$ & Yes & No & No & Yes & $\begin{array}{l}\text { IATTC C-02-03, reduction in fishing } \\
\text { capacity in purse-seine fisheries; C-02- } \\
04, \mathrm{C}-03-12, \mathrm{C}-04-09, \mathrm{C}-10-01, \mathrm{~A} \\
\text { seasonal closure of the purse seine } \\
\text { fishery in an area known as "El } \\
\text { Corralito", near Galapagos. }\end{array}$ & $2-6$ \\
\hline $\begin{array}{l}\text { ALB- } \\
\text { MED }\end{array}$ & 1984 & 11 & $\begin{array}{l}\text { No } \\
\text { quota }\end{array}$ & No & No & No & No & No management measures in effect. & \\
\hline $\begin{array}{l}\text { ALB-N- } \\
\mathrm{AO}\end{array}$ & 1950 & 30 & 2001 & No & No & No & Yes & $\begin{array}{l}\text { ICCAT Rec. } 98-08 \text {, limits on number of } \\
\text { fishing vessels to } 1993-1995 \text { average. }\end{array}$ & 8 \\
\hline $\begin{array}{l}\text { ALB-S- } \\
\mathrm{AO}\end{array}$ & 1960 & 24 & 1998 & No & No & No & No & $\begin{array}{l}\text { No other management measures in } \\
\text { effect rather than TAC. }\end{array}$ & \\
\hline $\begin{array}{l}\text { BET- } \\
\mathrm{AO}\end{array}$ & 1965 & 42 & 2005 & Yes & No & No & Yes & $\begin{array}{l}\text { ICCAT Rec. 09-01, Rec. 06-01, limits } \\
\text { on numbers of fishing vessels less than } \\
\text { average } 1991-1992 \text {; limits of number of } \\
\text { longline and purse seine boats for some } \\
\text { countries; ICCAT Rec. 04-01, No purse } \\
\text { seine and baitboat fishing during } \\
\text { November in the area encompassed by } \\
0^{\circ}-5^{\circ} \mathrm{N} \text { and } 10^{\circ} \mathrm{W}-20^{\circ} \mathrm{W} \text {. }\end{array}$ & $9-11$ \\
\hline $\begin{array}{l}\text { BUM- } \\
\text { AO }\end{array}$ & 1960 & 32 & $2013 *$ & No & Yes & Yes & No & $\begin{array}{l}\text { ICCAT Rec. } 02-13 \text {, stock under a } \\
\text { formal rebuilding plan since } 2003 \text {, } \\
\text { which includes minimum size } \\
\text { regulation for recreational fisheries and } \\
\text { catch limits. }\end{array}$ & 12 \\
\hline
\end{tabular}




\begin{tabular}{|c|c|c|c|c|c|c|c|c|c|}
\hline $\begin{array}{l}\text { BFT-E- } \\
\text { AO }\end{array}$ & 1950 & 23 & 1999 & Yes & No & Yes & Yes & $\begin{array}{l}\text { Formal Rebuilding plan since } 2007 \text {; } \\
\text { Rec. } 06-05 \text {, Rec. } 08-05 \text {, Rec. } 13-08 \text {, } \\
\text { which includes minimum size } \\
\text { regulation, and limits in fishing } \\
\text { capacity; Rec. } 09-06 \text {, calls for a } \\
\text { seasonal closure for purse seiners in the } \\
\text { eastern Atlantic and Mediterranean } \\
\text { between May } 15 \text { and June } 15 .\end{array}$ & $13-16$ \\
\hline $\begin{array}{l}\text { BFT- } \\
\text { W-AO }\end{array}$ & 1962 & 9 & 1982 & Yes & No & Yes & Yes & $\begin{array}{l}\text { ICCAT Rec. } 98-07 \text {, Rec. } 13-09 \text {, formal } \\
\text { Rebuilding plan since } 1999 \text {, with } \\
\text { minimum regulation sizes and limits in } \\
\text { fishing capacity. ICCAT Rec. 06-06: no } \\
\text { directed fishery on bluefin tuna in } \\
\text { spawning areas such as the Gulf of } \\
\text { Mexico. }\end{array}$ & $17-19$ \\
\hline $\begin{array}{l}\text { SAI-E- } \\
\text { AO }\end{array}$ & 1974 & 20 & $\begin{array}{l}\text { No } \\
\text { quota }\end{array}$ & No & No & No & No & No management measures in effect. & \\
\hline $\begin{array}{l}\text { SAI-W- } \\
\text { AO }\end{array}$ & 1964 & 19 & $\begin{array}{l}\text { No } \\
\text { quota }\end{array}$ & No & No & No & No & No management measures in effect. & \\
\hline $\begin{array}{l}\text { SKJ-E- } \\
\text { AO }\end{array}$ & 1970 & 27 & $\begin{array}{l}\text { No } \\
\text { quota }\end{array}$ & Yes & No & No & No & $\begin{array}{l}\text { ICCAT Rec. } 04-01 \text {, no purse seine and } \\
\text { baitboat fishing during November in the } \\
\text { area encompassed by } 0^{\circ}-5^{\circ} \mathrm{N} \text { and } 10^{\circ} \mathrm{W}- \\
20^{\circ} \mathrm{W} \text {. }\end{array}$ & 11 \\
\hline $\begin{array}{l}\text { SKJ-W- } \\
\text { AO }\end{array}$ & 1980 & 21 & $\begin{array}{l}\text { No } \\
\text { quota }\end{array}$ & No & No & No & No & No management measures in effect. & \\
\hline $\begin{array}{l}\text { SWO- } \\
\text { MED }\end{array}$ & 1972 & 14 & $\begin{array}{l}\text { No } \\
\text { quota }\end{array}$ & No & No & Yes & No & $\begin{array}{l}\text { ICCAT Rec. } 03-04 \text {, reduction of } \\
\text { juvenile swordfish mortality and } \\
\text { driftnet ban. }\end{array}$ & 20 \\
\hline $\begin{array}{l}\text { SWO- } \\
\text { N-AO }\end{array}$ & 1959 & 30 & 1997 & No & No & Yes & No & $\begin{array}{l}\text { ICCAT Rec. 01-04, Rec. 06-02, Rec. } \\
\text { 11-02, Formal Rebuilding Plan since } \\
\text { 1999, including minimum size } \\
\text { regulations and TAC. }\end{array}$ & $21-23$ \\
\hline $\begin{array}{l}\text { SWO- } \\
\text { S-AO }\end{array}$ & 1970 & 22 & 1998 & No & No & Yes & No & $\begin{array}{l}\text { ICCAT Rec 01-04. Minimum size } \\
\text { regulations. }\end{array}$ & 21 \\
\hline WHM & 1962 & 24 & $2013 *$ & No & Yes & Yes & No & $\begin{array}{l}\text { ICCAT Rec. } 02-13 \text {, stock under a } \\
\text { formal rebuilding plan since } 2003 \text {, } \\
\text { which includes minimum size } \\
\text { regulation for recreational fisheries and } \\
\text { catch limits. }\end{array}$ & 12 \\
\hline $\begin{array}{l}\text { YFT- } \\
\text { AO }\end{array}$ & 1959 & 49 & $2013 *$ & Yes & No & No & Yes & $\begin{array}{l}\text { ICCAT Rec. 09-01, Rec. 06-01, Limits } \\
\text { on numbers of fishing vessels less than } \\
\text { average 1991-1992; limits of number of } \\
\text { longline and purse seine boats for some } \\
\text { countries; ICCAT Rec. 04-01, No purse } \\
\text { seine and baitboat fishing during } \\
\text { November in the area encompassed by } \\
0^{\circ}-5^{\circ} \mathrm{N} \text { and } 10^{\circ} \mathrm{W}-20^{\circ} \mathrm{W} \text {. }\end{array}$ & $9-11$ \\
\hline ALB-IO & 1959 & 30 & $\begin{array}{l}\text { No } \\
\text { quota }\end{array}$ & No & No & No & Yes & $\begin{array}{l}\text { IOTC CMM. 12-11: limits in fishing } \\
\text { capacity. CMM. 12-13, one-month } \\
\text { closure for purse seiners and longliners } \\
\text { in an area of size } 10 \times 20 .^{*}\end{array}$ & $24-25$ \\
\hline BET-IO & 1975 & 33 & $\begin{array}{l}\text { No } \\
\text { quota }\end{array}$ & No & Yes & No & Yes & $\begin{array}{l}\text { IOTC CMM. 12-11: limits in fishing } \\
\text { capacity. CMM. 05-01. Catch limits. } \\
\text { CMM. 12-13, one-month closure for } \\
\text { purse seiners and longliners in an area } \\
\text { of size 10x20. }{ }^{*}\end{array}$ & $24-26$ \\
\hline
\end{tabular}




\begin{tabular}{|c|c|c|c|c|c|c|c|c|c|}
\hline $\begin{array}{l}\text { BUM- } \\
\text { IO }\end{array}$ & 1983 & 25 & $\begin{array}{l}\text { No } \\
\text { quota }\end{array}$ & No & No & No & Yes & $\begin{array}{l}\text { IOTC CMM. 12-11: limits in fishing } \\
\text { capacity. CMM. } 12-13 \text {, one-month } \\
\text { closure for purse seiners and longliners } \\
\text { in an area of size } 10 \times 20 .{ }^{*}\end{array}$ & $24-25$ \\
\hline SKJ-IO & 1956 & 33 & $\begin{array}{l}\text { No } \\
\text { quota }\end{array}$ & No & No & No & Yes & $\begin{array}{l}\text { IOTC CMM. 12-11: limits in fishing } \\
\text { capacity. CMM. } 12-13 \text {, one-month } \\
\text { closure for purse seiners and longliners } \\
\text { in an area of size } 10 \times 20 .{ }^{*}\end{array}$ & $24-25$ \\
\hline $\begin{array}{l}\text { MLS- } \\
\text { IO }\end{array}$ & 1985 & 25 & $\begin{array}{l}\text { No } \\
\text { quota }\end{array}$ & No & No & No & Yes & $\begin{array}{l}\text { IOTC CMM. 12-11: limits in fishing } \\
\text { capacity. CMM. } 12-13 \text {, one-month } \\
\text { closure for purse seiners and longliners } \\
\text { in an area of size } 10 \times 20 .^{*}\end{array}$ & $24-25$ \\
\hline $\begin{array}{l}\text { SWO- } \\
\text { IO }\end{array}$ & 1956 & 30 & $\begin{array}{l}\text { No } \\
\text { quota }\end{array}$ & No & No & No & Yes & $\begin{array}{l}\text { IOTC CMM. 12-11: limits in fishing } \\
\text { capacity. CMM. 12-13, one-month } \\
\text { closure for purse seiners and longliners } \\
\text { in an area of size } 10 \times 20 .^{*}\end{array}$ & $24-25$ \\
\hline YFT-IO & 1992 & 39 & $\begin{array}{l}\text { No } \\
\text { quota }\end{array}$ & No & No & No & Yes & $\begin{array}{l}\text { IOTC CMM. 12-11: limits in fishing } \\
\text { capacity. CMM. } 12-13 \text {, one-month } \\
\text { closure for purse seiners and longliners } \\
\text { in an area of size } 10 \times 20 .^{*}\end{array}$ & $24-25$ \\
\hline $\begin{array}{l}\text { ALB-N- } \\
\text { PO }\end{array}$ & 1985 & 15 & $\begin{array}{l}\text { No } \\
\text { quota }\end{array}$ & No & No & No & Yes & $\begin{array}{l}\text { WCPFC CMM } 2005-03 \text { and IATTC C- } \\
05-02 \text { called for members not to } \\
\text { increase fishing effort directed at North } \\
\text { Albacore. }\end{array}$ & $27-28$ \\
\hline $\begin{array}{l}\text { ALB-S- } \\
\text { PO }\end{array}$ & 1950 & 25 & $\begin{array}{l}\text { No } \\
\text { quota }\end{array}$ & No & No & No & Yes & $\begin{array}{l}\text { WCPFC CMM 2005-02, no increase of } \\
\text { number of vessels south of } 20 \text { S from } \\
2000-2004 \text { levels. }\end{array}$ & 29 \\
\hline $\begin{array}{l}\text { BET- } \\
\text { WCPO }\end{array}$ & 1960 & 35 & $\begin{array}{l}\text { No } \\
\text { quota }\end{array}$ & No & Yes & No & Yes & $\begin{array}{l}\text { WCPFC CMM-2005-01, CMM-2008- } \\
01 \text {, catch limits and reduction of fishing } \\
\text { effort. Also, CMM-2013-01, calls for a } \\
3 \text { months (July, August and September) } \\
\text { prohibition of setting on FADs for all } \\
\text { purse seine vessels. * }\end{array}$ & $30-31$ \\
\hline $\begin{array}{l}\text { BUM- } \\
\text { PO }\end{array}$ & 1957 & 35 & $\begin{array}{l}\text { No } \\
\text { quota }\end{array}$ & No & No & No & No & No management measures in effect & \\
\hline PBF & 1953 & 5 & $2014 *$ & No & No & No & No & $\begin{array}{l}\text { CMM } 2009-07 \text {, total fishing effort in } \\
\text { the area north of the } 20 \text { degrees north } \\
\text { shall not be increased from the } 2002- \\
2004 \text { level for } 2010^{*} \text {; IATTC C-13-02, } \\
\text { implementation of TAC. * }\end{array}$ & $32-33$ \\
\hline $\begin{array}{l}\text { SKJ- } \\
\text { WCPO }\end{array}$ & 1952 & 35 & $\begin{array}{l}\text { No } \\
\text { quota }\end{array}$ & No & No & No & No & No management measures in effect. & \\
\hline $\begin{array}{l}\text { MLS- } \\
\text { SWPO }\end{array}$ & 1978 & 25 & $\begin{array}{l}\text { No } \\
\text { quota }\end{array}$ & No & No & No & Yes & $\begin{array}{l}\text { CMM-2006-04, shall limit the number } \\
\text { of their fishing vessels fishing for } \\
\text { striped marlin in the Convention Area } \\
\text { south of } 150^{\circ} \mathrm{S} \text {, to the number in any } \\
\text { one year between the period } 2000 \text { - } \\
2004 \text {. }\end{array}$ & 34 \\
\hline $\begin{array}{l}\text { MLS- } \\
\text { WCPO }\end{array}$ & 1954 & 35 & $\begin{array}{l}\text { No } \\
\text { quota }\end{array}$ & No & No & No & No & $\begin{array}{l}\text { CMM 2010-01, total catch of North } \\
\text { Pacific Striped Marlin will be subject to } \\
\text { a phased reduction such that by } 1 \\
\text { January } 2013 \text { the catch is } 80 \% \text { of the } \\
\text { levels caught in } 2000 \text { to } 2003 . *\end{array}$ & 35 \\
\hline $\begin{array}{l}\text { SWO- } \\
\text { N-PO }\end{array}$ & 1951 & 15 & $\begin{array}{l}\text { No } \\
\text { quota }\end{array}$ & No & No & No & No & No management measures in effect. & \\
\hline
\end{tabular}


YFT-

1952

35

No

No

Yes

No

Yes

WCPFC CMM-2005-01, CMM-2008-

$30-31$

01 , catch limits and reduction of fishing effort. Also, CMM-2013-01, calls for a

3 months (July, August and September) prohibition of setting on FADs for all purse seine vessels. *

BLM- $\quad 1977$

IO

25

No

No

No

No

Yes

IOTC CMM. 12-11: limits in fishing capacity. CMM. 12-13, one-month closure for purse seiners and longliners in an area of size $10 \times 20 . *$

SWO-

1988

18

No

No

No

No

No

No management measures in effect

$650 *$ Management measures in effect in recent years (less than 5 years from the last assessment); it is too early to see the effects. 


\section{Figure Legends}

653

654

655

656

657

658

659

660

661

662

663

664

665

666

667

668

669

670

671

672

673

674

Figure 1. Geographical patterns of total cumulative catch $(1950-2012)$ in tones by $5 \times 5^{\circ}$ of major tuna and billfish species. Within each panel, different color shading is used to represent individual species. The top right panel shows the areas governed by the five tuna regional fisheries management organizations: ICCAT= International Commission for the Conservation of Atlantic Tunas; IOTC= Indian Ocean Tuna Commission; IATTC= Inter-American Tropical Tuna Commission (dashed red lines); WCPFC $=$ Western and Central Pacific Fisheries Commission (solid red line); and CCSBT= Commission for the Conservation of Southern Bluefin Tuna (blue shading).

Figure 2. Global catches and current status of tuna and billfish stocks. (a) Time trends of tuna catches by stock. The eight with greatest catches are highlighted in color. (b) Time trends in billfish catches by stock. Stock status relative to target reference points (dashed lines) for fishing mortality $\left(F_{\mathrm{MSY}}\right)$ and biomass $\left(B_{\mathrm{MSY}}\right)$ for $(\mathrm{c})$ tunas and $(\mathrm{d})$ billfishes. Horizontal and vertical dashed lines show MSY target reference points commonly used among tRFMOs. The area of circles within each plot is proportional to MSY (mt).

Figure 3. Variable importance score of different predictors on the current stock status $\left(B / B_{\mathrm{MSY}}\right.$ and $F / F_{\mathrm{MSY}}$ ) of tunas and billfishes. The most influential variables are those with the greatest decrease in accuracy. Variables in the grey shaded area are considered as not influential. They are significant if their importance value is above the absolute value of the lowest negativescoring variable. Log refers to the natural logarithm. 
Figure 4. Partial dependence plots of the most important continuous predictors of stock status.

The geometric mean of $B / B_{\mathrm{MSY}}$ and $F / F_{\mathrm{MSY}}$ correspond to the 10 years prior to the last assessment for each stock. Red lines represent tunas, blue lines billfishes and black lines both combined. Dashed lines show general management targets. Ln refers to the natural logarithm and the tic marks on the $\mathrm{x}$-axis represent the data available.

Figure 5. Effect of current management measures on tuna and billfish stocks. Geometric means of (a) $B / B_{\mathrm{MSY}}$ and (b) $F / F_{\mathrm{MSY}}$ over the final 10 years from the latest stock assessment. Dashed lines represent target reference points ( $B_{\mathrm{MSY}}$ and $\left.F_{\mathrm{MSY}}\right)$. Annual mean rates of change of (c) biomass and (d) fishing mortality. Dashed lines represent no changes in $B$ or $F$. In all panels, stocks are categorized by whether there are no management measures in effect, some input management measures, or output measures (TACs), and separated by taxa (tunas or billfishes). The area of circles within each plot is proportional to MSY (mt).

Figure 6. Variable importance scores of different management measures on stock rebuilding. The response variables are the geometric mean of the annual rates of change of biomass $(B)$ and fishing mortality rates $(F)$ for stocks declared overfished or experiencing overfishing 10 years before the last assessment. The most influential variables are those with the greatest decrease in accuracy. Variables in the grey shaded area are considered not influential. They are significant if their importance value is above the absolute value of the lowest negative-scoring variable.

Figure 7. Change in status $\left(B / B_{\mathrm{MSY}}\right.$ and $\left.F / F_{\mathrm{MSY}}\right)$ for stocks declared overfished or experiencing overfishing 10 years before the last assessment to the present. Results are shown for stocks with 
699 and without TAC regulations. Vertical and horizontal lines represent target reference points (for $700 \quad B_{\mathrm{MSY}}$ and $F_{\mathrm{MSY}}$, respectively). 

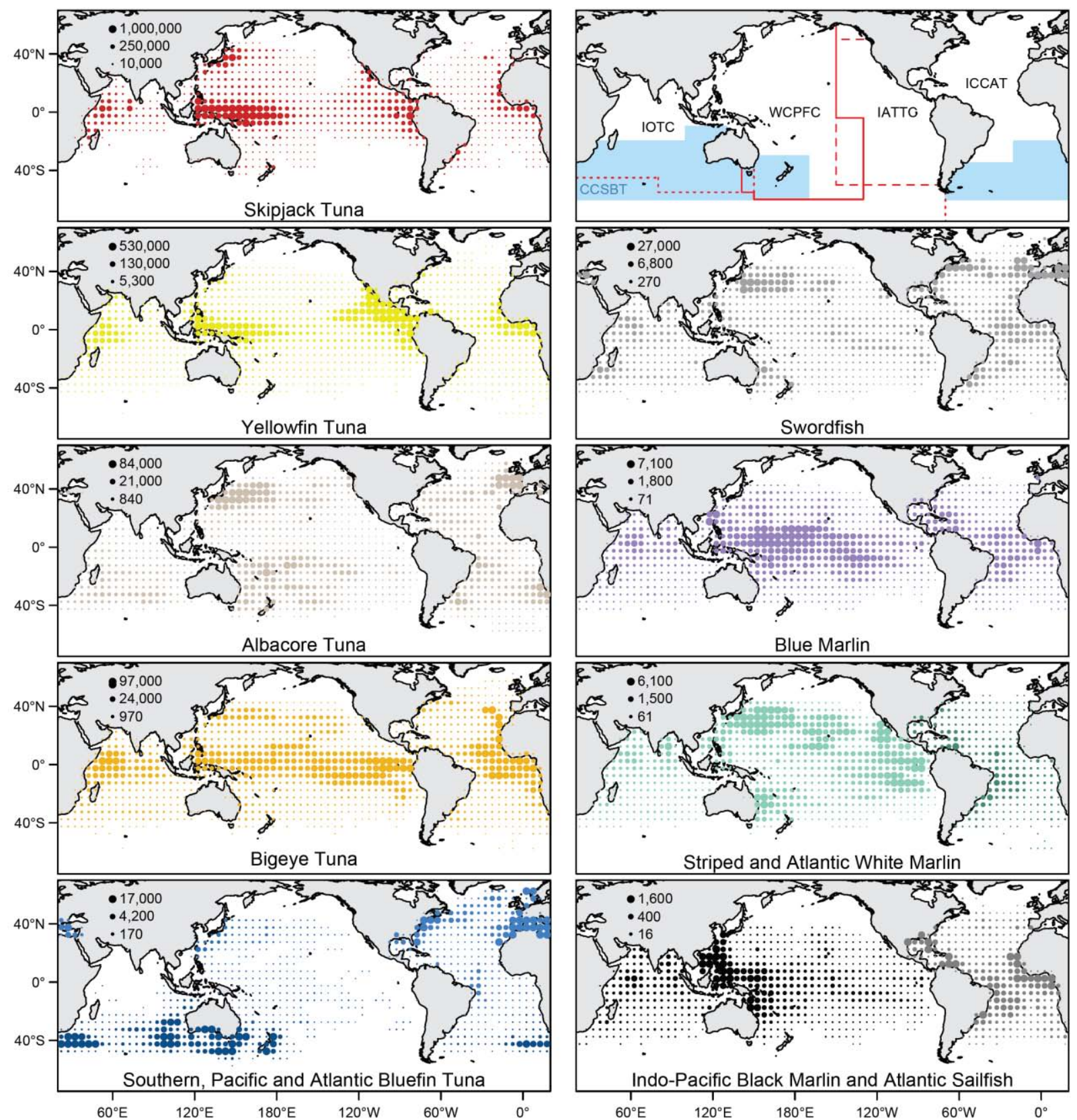

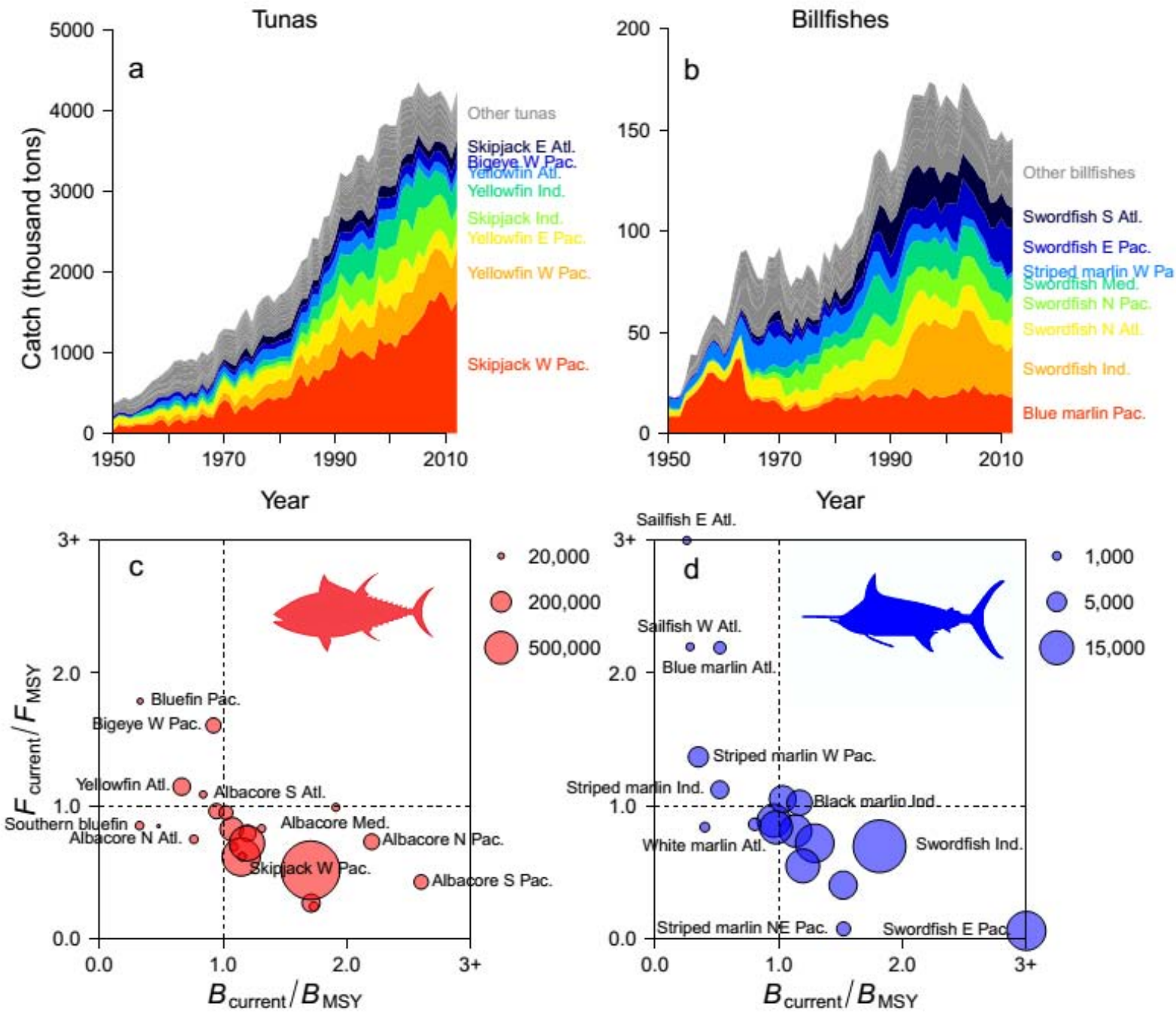

706

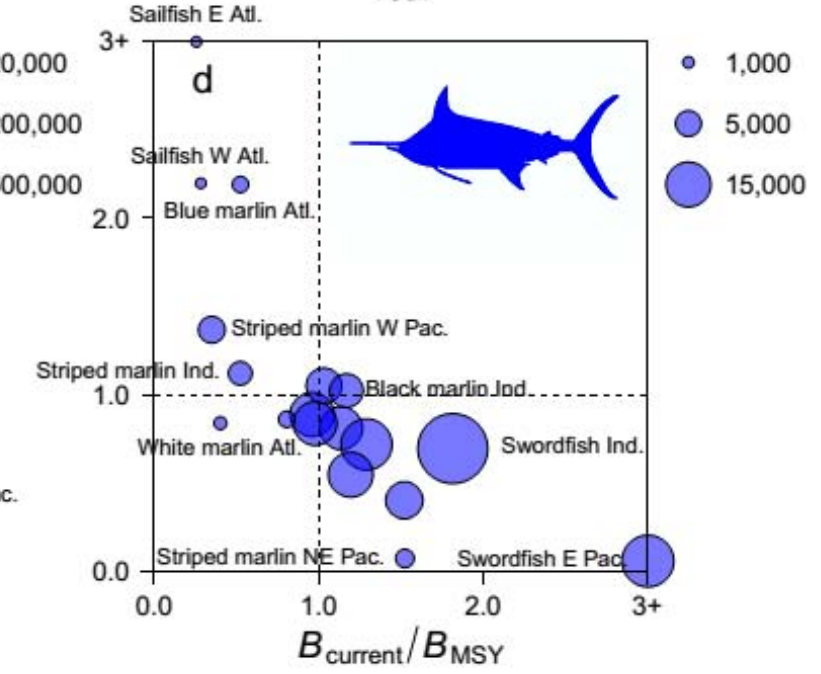

707 


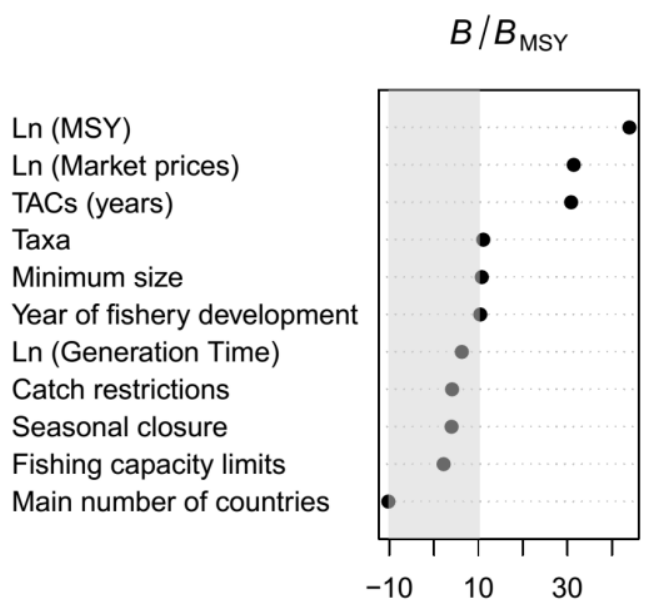

Mean decrease in accuracy

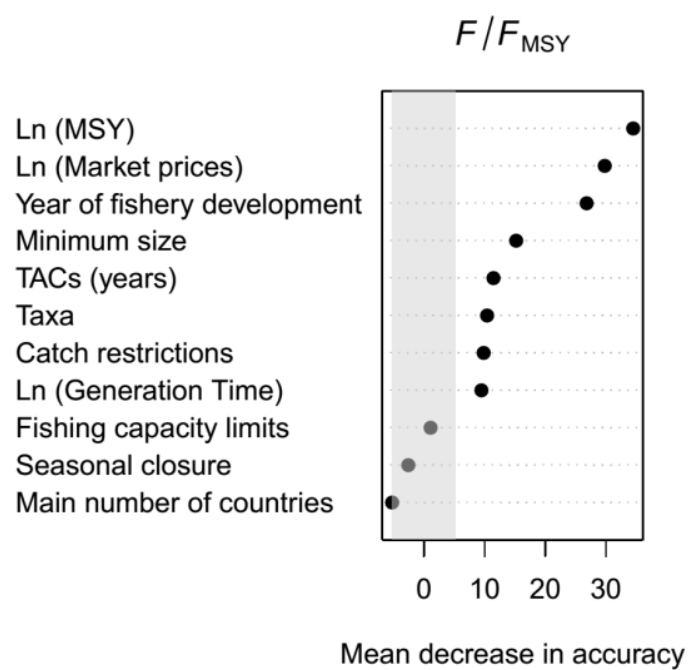

711 
714
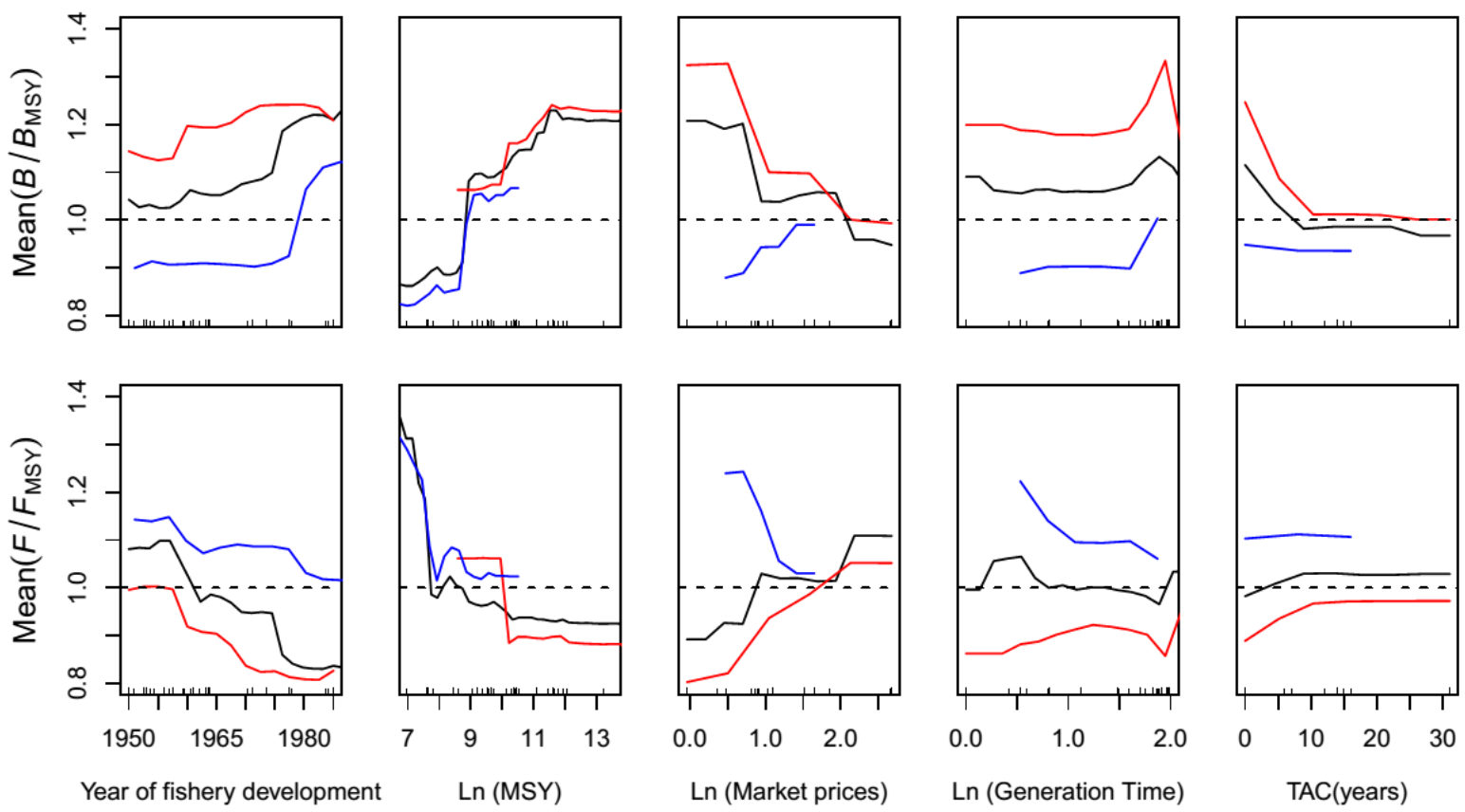

715

716 

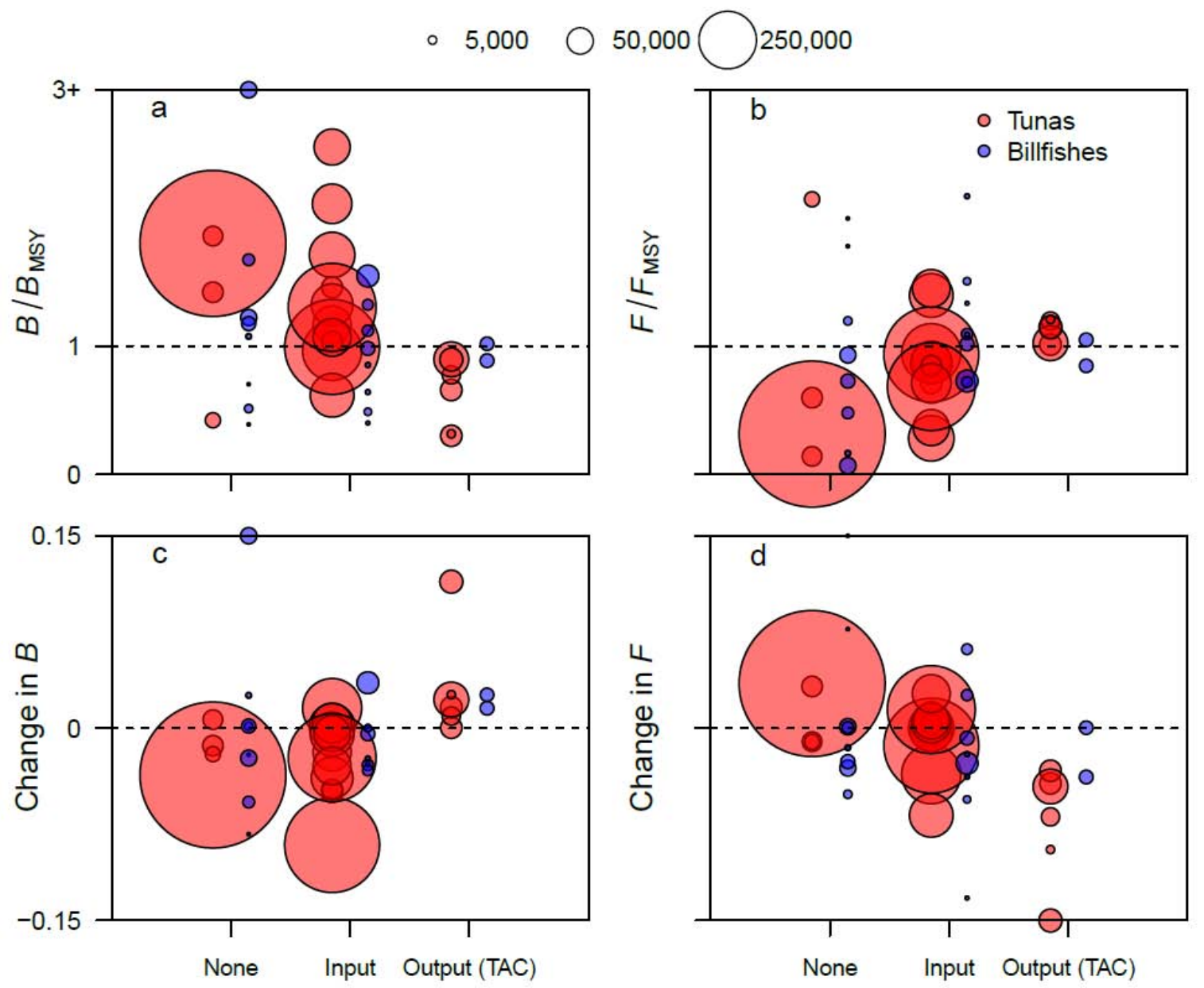


\section{$721 \quad$ Figure 6}

Change in $B$

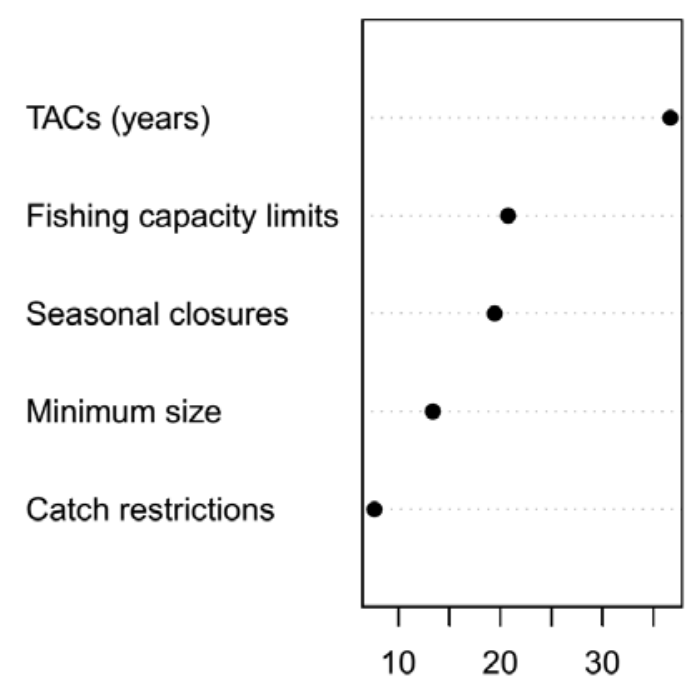

Mean decrease in accuracy
Change in $F$

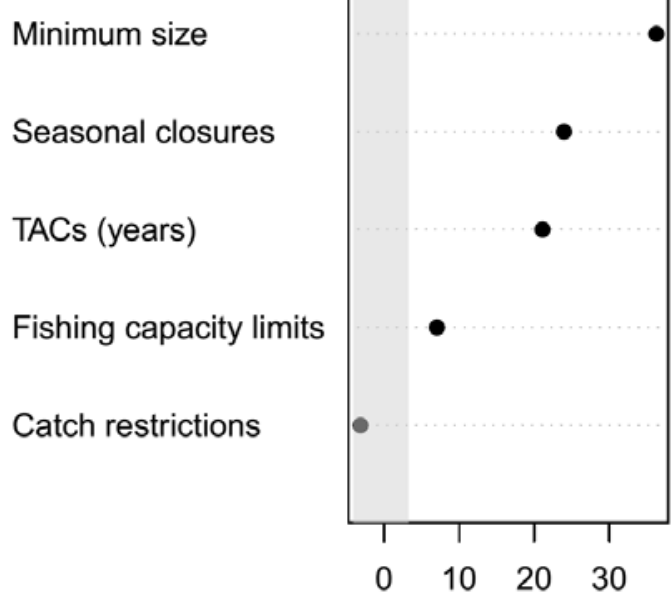

Mean decrease in accuracy 
Figure 7

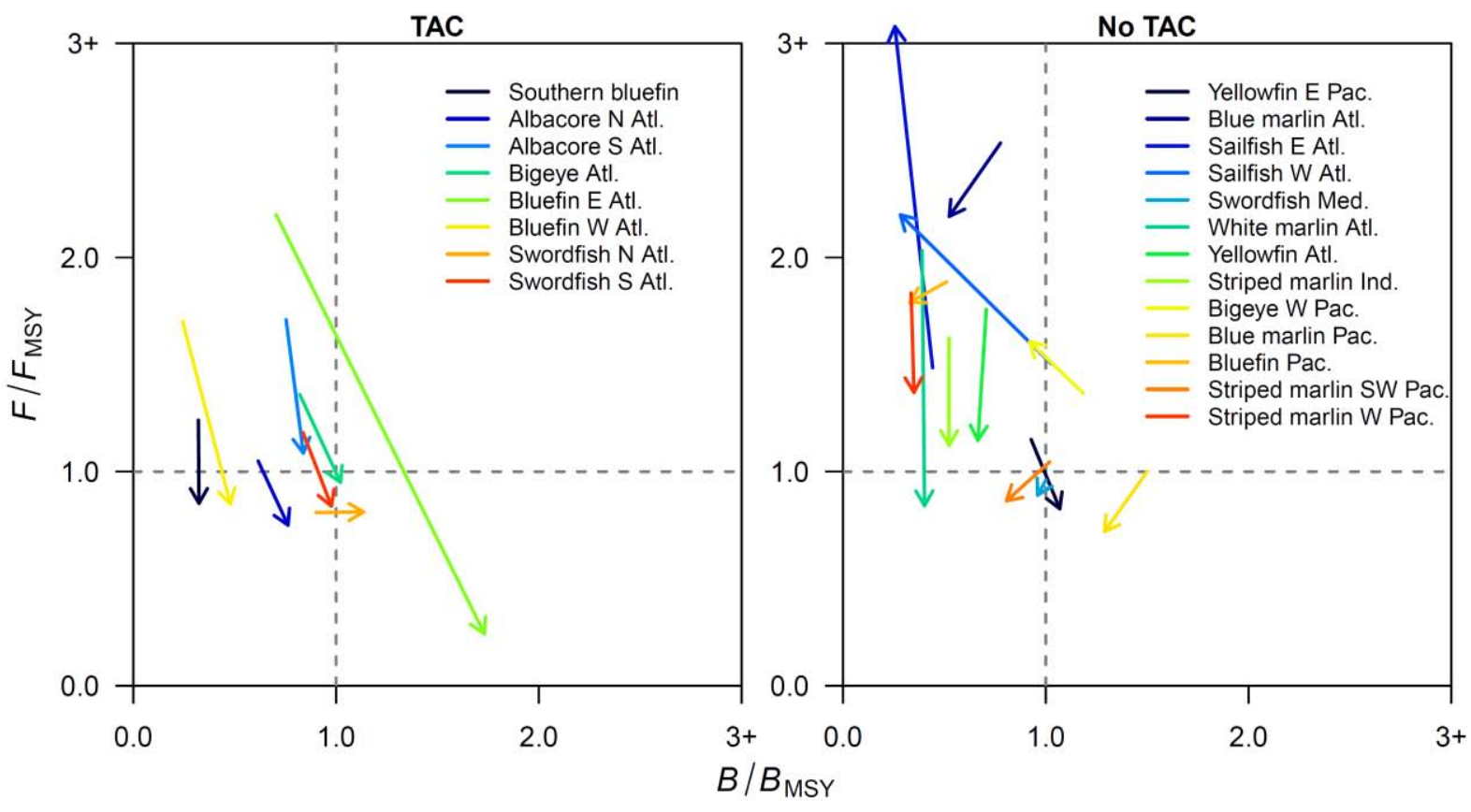

724 